\title{
Review \\ Diabetes Mellitus and Cardiovascular Diseases: Nutraceutical Interventions Related to Caloric Restriction
}

\author{
Pamela Senesi ${ }^{1,2} \mathbb{D}$, Anna Ferrulli ${ }^{1,2} \mathbb{D}$, Livio Luzi 1,2 and Ileana Terruzzi 1,2,* \\ 1 Department of Biomedical Sciences for Health, Università degli Studi di Milano, 20131 Milan, Italy; \\ pamela.senesi@unimi.it (P.S.); anna.ferrulli@unimi.it (A.F.); livio.luzi@unimi.it (L.L.) \\ 2 Department of Endocrinology, Nutrition and Metabolic Diseases, IRCCS MultiMedica, Sesto San Giovanni, \\ 20099 Milan, Italy \\ * Correspondence: ileana.terruzzi@unimi.it
}

Citation: Senesi, P.; Ferrulli, A.; Luzi, L.; Terruzzi, I. Diabetes Mellitus and

Cardiovascular Diseases:

Nutraceutical Interventions Related to Caloric Restriction. Int. J. Mol. Sci. 2021, 22, 7772. https://doi.org/ $10.3390 /$ ijms 22157772

Academic Editors: Maurizio Forte and Albino Carrizzo

Received: 21 June 2021

Accepted: 18 July 2021

Published: 21 July 2021

Publisher's Note: MDPI stays neutral with regard to jurisdictional claims in published maps and institutional affiliations.

Copyright: (c) 2021 by the authors. Licensee MDPI, Basel, Switzerland This article is an open access article distributed under the terms and conditions of the Creative Commons Attribution (CC BY) license (https:// creativecommons.org/licenses/by/ $4.0 /)$.

\begin{abstract}
Type 2 diabetes (T2DM) and cardiovascular disease (CVD) are closely associated and represent a key public health problem worldwide. An excess of adipose tissue, NAFLD, and gut dysbiosis establish a vicious circle that leads to chronic inflammation and oxidative stress. Caloric restriction (CR) is the most promising nutritional approach capable of improving cardiometabolic health. However, adherence to CR represents a barrier to patients and is the primary cause of therapeutic failure. To overcome this problem, many different nutraceutical strategies have been designed. Based on several data that have shown that CR action is mediated by AMPK/SIRT1 activation, several nutraceutical compounds capable of activating AMPK/SIRT1 signaling have been identified. In this review, we summarize recent data on the possible role of berberine, resveratrol, quercetin, and L-carnitine as CR-related nutrients. Additionally, we discuss the limitations related to the use of these nutrients in the management of T2DM and CVD.
\end{abstract}

Keywords: diabetes; cardiovascular diseases; caloric restriction; berberine; resveratrol; quercetin; L-carnitine

\section{Introduction}

\subsection{Diabetes and Cardiovascular Diseases}

The prevalence of type 2 diabetes mellitus (T2DM), the most common form of diabetes, has rapidly increased and currently represents a devastating socioeconomic burden worldwide.

The diabetic condition is a crucial risk factor for the onset of cardiovascular diseases (CVD), including retinopathy, stroke, and cardiac damages [1]. T2DM is linked to coronary heart disease, myocardial stroke, and diabetic cardiomyopathy [2,3].

It is important to point out that T2DM and CVD mutually strengthen each other, increasing the hospitalization rate and mortality. High glucose levels and in particular glucose fluctuations impair energy production, excitation, and contraction of cardiac cells, favoring the onset of several cardiac pathologies, including atrial fibrillation. In addition, hyperglycemia modifies cardiac intracellular pathways, increasing the synthesis of reactive oxygen species (ROS) and inflammatory mediators [4-6]. Oxidative stress impairs the capacity of heart cells to respond to injuries: the effectiveness of traditional and innovative cardiac treatments aimed at recovering myocardial function after infarction is limited in diabetes patients $[3,7,8]$. Moreover, chronic hyperglycemia, increasing ROS production, leads to the development of endothelial dysfunction that significantly contributes to the pathogenesis of micro- and macrovascular diseases [9].

Not only oxidative stress but also chronic low-grade inflammation is a key pathological mechanism involved in T2DM and CVD [9,10]. Excessive depots of adipose tissue and microbiota dysbiosis cause a pro-inflammatory microenvironment [10-12] (Figure 1). White adipose tissue is characterized by improved macrophage infiltration that is associated with increased systemic insulin resistance condition. Moreover, adipose tissue, as an endocrine 
organ, secretes different adipokines and above all several inflammatory mediators, including tumor necrosis factor (TNF)- $\alpha$ and interleukin (IL)-6, that play a crucial role in systemic low-grade inflammation state [10]. It is important to note that recent investigations have demonstrated that adipokines interacts with myokines modulating cardiovascular function. For example, apelin, an adipokine, ameliorates hypertension and endothelial dysfunction and counteracts infarct damages, decreasing ROS production [13,14].
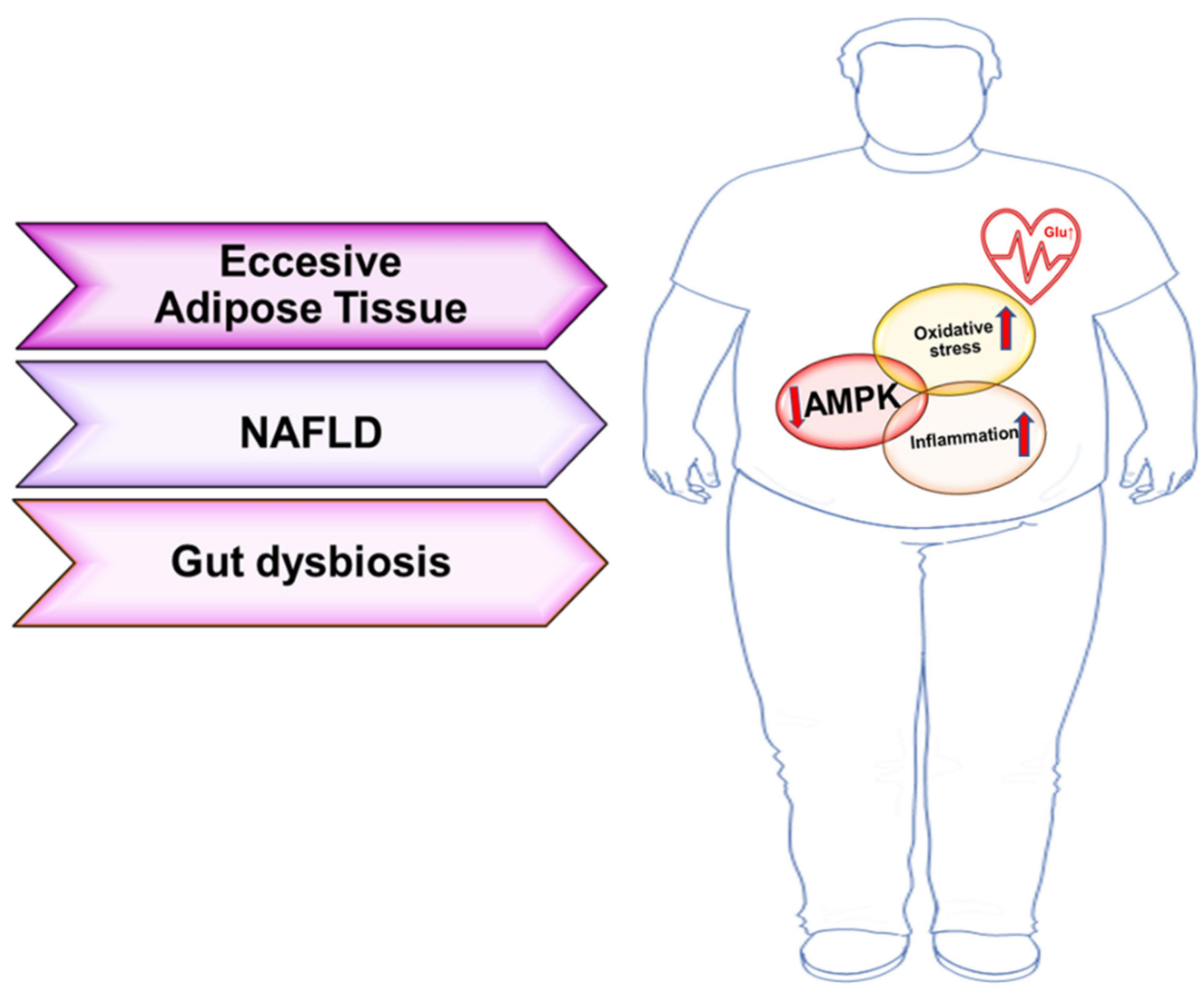

Figure 1. Schematic representation of the strong interconnection between T2DM and CVD. Excessive adipose depots, gut dysbiosis, and NAFLD are key risk factors that promote T2DM and CVD. At the molecular level, oxidative stress and inflammatory condition are the primary mediators of metabolic and cardiac damages. These processes are orchestrated by AMPK impaired signaling (modified by Servier Medical Art by Servier is licensed under a Creative Commons Attribution 3.0 Unported License).

Impaired composition and reduced diversity of gut microbial community are correlated with a decreased insulin sensitivity and worsening of the inflammatory state [15-17]. An unbalanced ratio of Firmicutes/Bacteroidetes, the two principal phyla of gut microbiota, damages the gut mucosal barrier and thus increasing the translocation of lipopolysaccharide (LPS), which is a component of Gram-negative bacteria, as well as contributing to the activation of inflammatory pathways, including Toll-like receptor $4[18,19]$. The subsequent abnormal production of cytokines exacerbates the inflammatory state in T2DM patients.

Moreover, gut dysbiosis plays a crucial role in non-alcoholic fatty liver disease (NAFLD), which is another typical comorbidity in T2DM patients with or without CVD [20] (Figure 1). Gut and liver are closely connected not only through the portal vein; accumulating data indicate that microbiota metabolites are capable of stimulating an important inflammatory response in liver, principally by Kupffer cells activation. Indeed, NAFLD patients are characterized by increased LPS levels [21]. In addition, gut metabolites increase insulin resistance and fat accumulation. Clinical studies have shown that the production of short-chain fatty acids by the microbial fermentation of dietary fibers is impaired in NAFLD subjects, inducing imbalance between energy harvest, expenditure, and mitochondrial 
dysfunction. The consequent overproduction of ROS and cytokines increases the risk of CDV onset in diabetic condition [22-24].

Lifestyle modifications, diet and physical activity, represent a primary cornerstone in the prevention and management of T2DM and CVD [25]. In this review, we will discuss emerging dietary interventions and principal food bioactive molecules that could represent an adjuvant therapeutic approach in T2DM/CVD management.

\subsection{New Dietary Interventions in T2DM/CVD Management}

The traditional nutrition approach is aimed at defining the correct intake of macronutrients and micronutrients to maintain ideal body composition and function [26], and consequently, traditional nutrition research, based mainly on epidemiological studies, has drawn up the dietary guidelines for the population.

In the last decades, sequencing of the human genome, "omics" technologies (genomics, transcriptomics, proteomics, and metabolomics) and progress in microbiota knowledge have allowed to make a Copernican revolution in nutrition research from "dietary for the population" to "personalized nutrition" $[27,28]$. Using "omics" technologies, several molecular events, i.e., pathways activation, epigenome stability, and protein expression, caused by nutrients intake have been identified. Now, the innovative goal of nutrition research is focused on identifying the relationship between food constituents and molecular targets $[29,30]$. This new approach of nutritional intervention, based on the molecular action of food and not only on nutritional value of food, represents the crucial therapeutic strategy in the T2DM and CVD.

\subsection{From Caloric Restriction to Caloric Restriction Mimetics}

For T2DM patients, reduced daily calorie intake is the gold standard of dietary therapeutic interventions [31]. Studies performed using different animal models and human clinical trials have demonstrated that caloric restriction (CR), a nutritional approach based on caloric intake decrease (between 20 and $40 \%$ ) without modifying the balance of micro/macronutrients, ameliorates cardiometabolic conditions and extends lifespan [30,31].

The CALERIE ${ }^{\mathrm{TM}}$ (Comprehensive Assessment of Long-term Effects of Reducing Intake of Energy) study is the first clinical trial focused on CR action [32]. It was organized in two different phases: in the first phase, different grades of CR $(20 \%, 25 \%$, and $30 \%)$ were tested in overweight subjects for six months to one year. In the second part of CALERIE $^{\mathrm{TM}}$, constituted by a multicenter, randomized controlled trial, CR $(25 \%)$ action was studied in healthy non-obese subjects for two years. Extensive parameters analyzed on different biological sample (serum, plasma, urine, and biopsies from skeletal muscle and adipose tissue subcutaneous abdominal) have demonstrated that after 2 years of $\mathrm{CR}$, all cardiometabolic risk factors have decreased compared to baseline. In addition, metabolic parameters, including insulin sensitivity index and metabolic syndrome score, have ameliorated relative to control [32-34].

At the molecular level, AMPK (AMP-activated protein kinase) is the crucial mediator of CR effects enhancing insulin-sensitizing action and consequently glucose uptake in skeletal muscles and decreasing hepatic glucose production and improving fatty acid oxidation [35-37]. Notably, AMPK improves healthspan and lifespan, as demonstrated by in vivo studies performed using CR diet or metformin, which is the most common drug to treat TDM2 and is capable of active AMPK signaling [38-41].

Data reported in literature have shown that AMPK, through increasing $\mathrm{NAD}^{(+)}$cellular levels, promotes the activity of Sirtuin 1 (SIRT1), which is a crucial $\mathrm{NAD}^{(+)}$-dependent histone deacetylase implicated in numerous cellular process from cell metabolism to cell growth [42-44]. Interestingly, AMPK and SIRT1 synergically act: Liver Kinase B1, a crucial upstream AMPK activator, is a main SIRT1 target [45]. Moreover, AMPK and SIRT1 have many common molecular targets involved in oxidative and inflammatory processes characterizing cardiometabolic pathologies, i.e., endothelial nitric oxide (NO) bioavailability, PCG-1 $\alpha$, and PPARs [38-42,46,47] (Figure 2). 


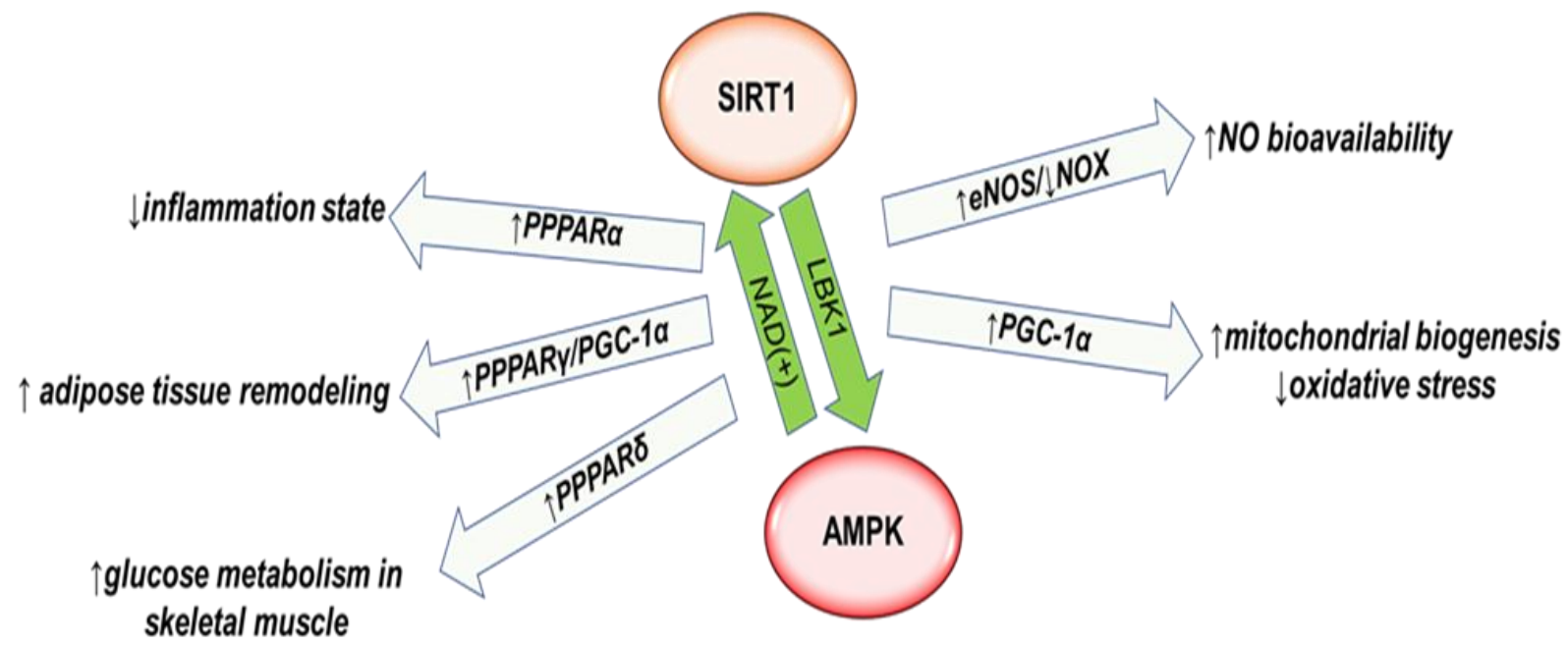

Figure 2. T2DM and CVD: AMPK-SIRT1 signaling cascade. AMPK, the main mediator of CR action, synergically acts with SIRT1. AMPK actives SIRT1, increasing NAD $^{(+)}$levels, while SIRT1 promotes AMPK activity by Liver Kinase B1 (LKB1). AMPK/SIRT1 regulating the eNOS/NOX ratio increases NO bioavailability and mitigates endothelial dysfunction. Moreover, AMPK and SIRT1 activated PGC-1 $\alpha$, which is the primary factor involved in mitochondrial biogenesis. Then, AMPK/SIRT1/PGC-1 $\alpha$ activation counteracts oxidative condition. PPARs are other common targets of SIRT1/AMPK: PPAR $\alpha$ activation is related to inflammation, PPAR $\gamma$, interacting with PGC- $1 \alpha$, improves adipose tissue plasticity and adipose browning tissue. Finally, PPAR $\delta$ upregulation improves glucose metabolism in skeletal muscle.

AMPK/SIRT1 action is related to endothelial nitric oxide (NO) bioavailability, which is significantly decreased in diabetic or cardiac patients [48,49], and it is correlated not only with endothelial function but also with oxidative and immune mechanisms [50]. Even if accumulating data have pointed out that diets rich in green leafy vegetables represent an important source of NO [51], the endothelial nitric oxide synthase (eNOS) enzyme is primary involved in NO production from the amino acid L-arginine [52]. It is well established that excessive oxidative stress impairs eNOS activity while NOX (Nicotinamide Adenine Dinucleotide Phosphate (NADPH) oxidase) enzymes, which are mainly responsible for ROS cellular generation, are upregulated $[48,53]$. In obesity or in a hyperglycemic state, ROS rapidly reacts with $\mathrm{NO}$, forming secondary reactive nitrogen species, including peroxynitrite, thus decreasing NO bioavailability. Unbalanced NO production exacerbates stress conditions, creating a vicious cycle that mainly causes vasodilation damages and increases low-grade inflammation. A growing body of evidence has indicated that CR ameliorates endothelial dysfunction, activating AMPK-eNOS signaling [54,55]. Different studies have demonstrated that AMPK increases eNOS expression in an indirect manner by the phosphatidylinositol-3-kinase-protein/AKT pathway [56,57]. In addition, it has recently been demonstrated by García-Prieto et al. that $\mathrm{Ca}^{2+} /$ calmodulin-dependent kinase II plays a crucial action in mediating CR-induced AMPK activation through $\mathrm{H}_{2} \mathrm{O}_{2}$ increase in aortas from obese rats [58]. In addition, AMPK improves NO bioavailability by downregulating NOX4 expression, as demonstrated by studies using different drugs able to active AMPK [59]. For instance, Hasan et al. have recently demonstrated that canagliflozin, a sodium-glucose cotransporter 2 (SGLT2) inhibitor used in T2DM treatment, ameliorates a cardiac oxidative microenvironment by AMPK/NOX4 signaling [60]. In the same manner, SIRT1 plays a fundamental role in eNO expression. In vivo studies have shown the interplay between SIRT1 and eNOS: CR actives SIRT1 that deacetylates and activates eNOS, while the acetylation of eNOS downregulates SIRT1 signaling [61]. Moreover, AMPK/SIRT1 activation enhancing eNOS signaling counteracts ischemia/reperfusion [62]. Finally, the closed relationship between SIRT1 and NOX is well recognized. Luo et al. have proven that dulaglutide, a common drug used in TDM2 treatment, activates SIRT1 and thus represses NOX4 expression in human umbilical vein endothelial cells [63]. 
PGC-1 $\alpha$, the primary factor involved in mitochondrial biogenesis [64], is activated by SIRT1 removing the acetyl groups, while AMPK-induced activation is mediated by a phosphorylation mechanism. AMPK/SIRT1/PGC-1 $\alpha$ action on mitochondrial biogenesis increases the expression of anti-oxidation genes, mitigating oxidative microenvironment and cardiac damages [35,65]. The activation of the SIRT1/PGC- $1 \alpha$ axis has been reported also by Waldman et al., who have observed an improvement of diabetic cardiomyopathy in $\mathrm{db} / \mathrm{db}$ mice by $\mathrm{CR}$ diet treatment associated with a significant enhancement of oxidative stress and inflammation state [66]. Moreover, recently, Mehrabani et al. have speculated that CR could play an important role in preserving the normal homeostasis of the mitochondria population, enhancing mitophagy [42], as has been observed by Gutierrez-Casado et al. in a murine model [43]. This action is correlated with the Fork Head Box O1 (FOXO) transcription factor family. In particular, FOXO1 coordinates the expression of the primary enzymes involved in ROS scavengers and is deacetylated by SIRT1 in a dependent or independent manner of AMPK activation [67-69].

Peroxisome proliferator-activated receptors (PPARs) are other common targets of SIRT1/ AMPK. PPARs interact with different co-regulators, including FOXO and PGC1- $\alpha$, and influence several cellular functions, i.e., cellular metabolism, skeletal muscle and adipose tissues differentiation, inflammation, and oxidative stress. PPAR $\alpha$ is involved in oxidative and inflammatory process. Kauppinen et al. have observed that PPAR $\alpha$, activated by SIRT1, inhibits NF-kB pathways and alleviates the inflammatory storm induced by hyperglycemia and lipotoxicity [70]. In addition, CR action on AMPK-PPAR $\alpha$ is associated with a reduced monocyte mobilization and consequently with an improvement of chronic inflammatory state [71]. In obese mice affected by cardiomyopathy, CR promotes PPAR $\alpha$ expression in the heart, reducing inflammation [72]. PPAR $\gamma$ is another member of the PPAR family that is primary involved in adipose tissue remodeling [73]. As is known, the modulation of adipose plasticity is a key mechanism to prevent cardiovascular complications in obese and diabetes patients, since white adipose tissue positively relates with high cardiometabolic risk, while brown adipose tissue and beige adipose tissue are negative correlated with cardiovascular risk [74]. PPAR $\gamma$ is activated by AMPK [75] or by SIRT1-mediated deacetylation [76] and interacts with PGC-1 $\alpha$, promoting the expression of mitochondrial uncoupling protein-1 expression (UCP1) and the recruitment of PRDM16, the main transcription factors involved in white adipose tissue browning [74,76-78]. In addition, PPAR $\gamma-$ PGC1 $\alpha$ upregulates UCP2 expression, which affects mitochondrial dysfunction and ROS accumulation [79]. Different data corroborate CR action on PPAR $\gamma-$ PGC1 $\alpha$ [80-82]. Finally, AMPK and SIRT1 also regulates PPAR $\delta$ expression [83,84]. This member of the PPAR family is high expressed in skeletal muscle and is involved in glucose metabolism [85]: its activation improves glucose oxidation and exercise performed [83,86].

Moreover, accumulating recent data suggest that $\mathrm{CR}$ contributes to maintain the health of the intestinal epithelial barrier and then counteracts the gut stress/inflammation process. Indeed, CR action decreases LPS production and modifies microbiota composition $[87,88]$. A growing number of data have pointed out that CR-induced microbiota improvement is correlated not only with mitigated hepatic lipid accumulation $[89,90]$ but also with increased fat adipose plasticity [73,91,92]. It is important to highlight that Correles et al. have demonstrated how, in a murine model, long-term CR has a strong impact on adipose plasticity, improving subcutaneous white adipose tissue expandability and the thermogenesis process of brown adipose tissue [92], as reported above, by PPAR $\gamma-\mathrm{PGC} 1 \alpha$ activation $[73,82]$.

Therefore, even if CR dietary protocol, activating fundamental metabolic and antioxidant pathways, is able to guarantee weight loss, but in daily clinical pratice its effectiveness is limited by the adherence of patients [93]. Numerous subjects follow a diet program for a few months and usually recover weight loss. To minimize this problem, several investigations have been carried out aimed at identifying easy-to-administer CR mimetics [94-97]. Different drugs, including metformin and aspirin, have been defined CR mimetics [40,97], but food bioactive molecules arouse greater attention considering their easier use. 


\section{From Caloric Restriction to CR-Related Nutrients: Berberine}

Berberine (BBR) is a component of many plants, i.e., Barberry, Berberis, Coptis chinensis, and Hydrastis, which is usually used in Chinese traditional medicine as an antibacterial drug [98].

The CR mimetic action of BBR has been established by numerous studies performed using in vitro and in vivo models of obesity or diabetes or cardiovascular pathological conditions [99,100]: BBR, activating mainly AMPK, reduces body weight and hepatic lipid accumulation, and it also improves insulin action [100-104]. Wu et al. have recently demonstrated that BBR not only increases glucose metabolism and the insulin signal pathway but also decreases inflammatory response in hepatocytes cultured in an insulinresistant condition [105]. In obese and diabetic animal models, BBR treatment is able to enhance the AMPK-PGC- $1 \alpha$ signaling pathway, mitigating the oxidative and fibrosis process caused by excessive adipose depots [106]. Moreover, it has been proven that in adipose tissue, SIRT1 is a main regulator of the insulin-sensitizing action of BBR [107]. BBRinduced SIRT1 activation is involved not only in the metabolic state but it also alleviates the inflammation state, decreasing the production inflammatory cytokines and macrophage infiltration [107]. Finally, as previous reported, AMPK activation is related to adipose tissue remodeling, and indeed, BBR promotes brown adipose tissue thermogenesis and white adipose tissue browning [108].

Further studies have highlighted BBR action on heart: Using an in vitro model of hyperglycemic cardiomyocytes, Hang et al. have observed that BBR, activating AMPK signaling, reduces ischemia/perfusion damages [109], and Chan et al. have confirmed these findings in a diabetic rat model [110]. As CR, BBR counteracts hyperglycemia-induced endothelial dysfunction through AMPK/eNOS signaling cascade activation [111].

Moreover, different authors have investigated BBR action on gut microbiota: BBR treatment modifies gut composition in animal models of obesity, alleviating the inflammation state induced by LPS overproduction and improving energy metabolism and insulin resistance condition [112-114]. In addition, in a mice model of atherosclerosis fed a high-fat diet, the modifications of microbiota composition induced by BBR are correlated with a significant decrease of inflammatory cytokine expression and an improvement of atherosclerosis state [115].

Taken together (Table 1), these results indicated that BRR acts in a similar manner to $\mathrm{CR}$, ameliorating cardiometabolic condition as underlined by different systematic reviews and a meta-analysis of randomized controlled trials [116-118].

Table 1. Berberine as a CR-related nutrient ( $\uparrow$ increase/improvement, $\downarrow$ decrease/worsening).

\begin{tabular}{|c|c|c|c|}
\hline Type of Studies & $\begin{array}{l}\text { Tissue Molecular } \\
\text { Mechanisms }\end{array}$ & Effects & References \\
\hline $\begin{array}{l}\text { In vitro and in vivo (obese } \\
\text { mice) }\end{array}$ & $\begin{array}{c}\text { Skeletal muscle: } \\
\uparrow \text { AMPK } / \text { PGC- } 1 \alpha \text { pathway } \\
\text { activation }\end{array}$ & $\begin{array}{c}\downarrow \text { lipid deposition in skeletal } \\
\text { muscle } \\
\uparrow \text { glucose metabolism } \\
\uparrow \text { mitochondrial biogenesis and } \\
\text { function }\end{array}$ & Yao et al. [103] \\
\hline In vitro study & $\begin{array}{l}\text { Hepatocytes (HepG2): } \\
\uparrow \text { AMPK } \alpha 1 \text { activation in }\end{array}$ & $\uparrow$ glucose and lipid metabolism & Ren et al. [104] \\
\hline $\begin{array}{l}\text { In vitro and in vivo (diabetic } \\
\text { rats) }\end{array}$ & Liver: $\uparrow$ PKA activation & $\downarrow$ inflammatory response & Wu et al. [105] \\
\hline In vivo (obese rats) & $\begin{array}{c}\text { Adipose tissue: } \uparrow \text { AMPK } \\
\text { activation }\end{array}$ & $\begin{array}{c}\downarrow \text { body weight } \\
\uparrow \text { glucose metabolism } \\
\downarrow \text { fibrosis response in adipose } \\
\text { tissue }\end{array}$ & Wang et al. [106] \\
\hline
\end{tabular}


Table 1. Cont.

\begin{tabular}{|c|c|c|c|}
\hline Type of Studies & $\begin{array}{l}\text { Tissue Molecular } \\
\text { Mechanisms }\end{array}$ & Effects & References \\
\hline In vitro and in vivo (obese rats) & $\begin{array}{c}\text { Adipose tissue: } \\
\uparrow \text { AMPK/SIRT1/PGC- } 1 \alpha \\
\text { activation }\end{array}$ & $\begin{array}{c}\uparrow \text { insulin sensitizing } \\
\downarrow \text { inflammation state } \\
\downarrow \text { macrophage infiltration }\end{array}$ & Shan et al. [107] \\
\hline $\begin{array}{c}\text { In vivo (obese mice) and clinical } \\
\text { study (overweight NAFLD } \\
\text { patients) }\end{array}$ & $\begin{array}{l}\text { Brown adipose tissue: } \\
\uparrow \text { AMPK/PRDM16 signaling } \\
\text { cascade }\end{array}$ & $\begin{array}{c}\uparrow \text { activation of brown adipose } \\
\text { tissue }\end{array}$ & Wu et al. [108] \\
\hline In vitro & $\begin{array}{l}\text { Cardiomyocytes grown in high } \\
\text { glucose: } \uparrow \text { AMPK/ activation }\end{array}$ & $\uparrow$ mitochondrial biogenesis & Hang et al. [109] \\
\hline $\begin{array}{l}\text { In vivo (diabetic rats with } \\
\text { cardiac ischemia) }\end{array}$ & $\begin{array}{l}\text { Non-ischemic areas of the } \\
\text { diabetic heart: } \uparrow \text { AMPK activity }\end{array}$ & $\begin{array}{l}\downarrow \text { damages induced by } \\
\text { ischemia-reperfusion injury }\end{array}$ & Chang et al. [110] \\
\hline In vitro & $\begin{array}{c}\text { Cultured endothelial cells and } \\
\text { blood vessels isolated from rat } \\
\text { aorta: } \\
\uparrow \mathrm{AMPK} / \mathrm{eNOS} \text { signaling }\end{array}$ & $\begin{array}{c}\uparrow \text { improved endothelial } \\
\text { dysfunction } \\
\uparrow \text { vasodilatation }\end{array}$ & Wang et al. [111] \\
\hline In vivo (obese rats) & $\begin{array}{c}\text { Liver: } \downarrow \text { Toll-like receptor } 4 \\
\text { (TLR4)/tumor necrosis factor } \\
\text { (TNF)- } \alpha \text { pathway }\end{array}$ & $\begin{array}{c}\uparrow \text { improved insulin resistance } \\
\downarrow \text { hepatic steatosis and LPS release }\end{array}$ & Liu et al. [112] \\
\hline $\begin{array}{l}\text { In vivo (Sprague-Dawley rats } \\
\text { and hamsters, obese mice) }\end{array}$ & $\begin{array}{l}\uparrow \text { Butyrate production by gut } \\
\text { microbiota }\end{array}$ & $\downarrow$ blood lipid and glucose levels & Wang et al. [113] \\
\hline In vitro and in vivo (mice) & $\begin{array}{c}\text { Gut microbiota: } \downarrow \text { Clostridium } \\
\text { species }\end{array}$ & activation of intestinal FXR & Tian et al. [114] \\
\hline $\begin{array}{l}\text { In vivo (obese male apoE } \\
\text { mice) }\end{array}$ & Modification of gut composition & $\begin{array}{c}\downarrow \text { atherosclerosis development, } \\
\text { inflammatory cytokine } \\
\text { expression, hepatic FMO3 } \\
\text { expression and TMAO }\end{array}$ & Shi et al. [115] \\
\hline
\end{tabular}

\section{From Caloric Restriction to CR-Related Nutrients: Resveratrol}

BBR is not the only food compound having CR mimetic propriety; the best-known food molecule characterized by CR mimetic action is certainly resveratrol (RSV). RSV is a natural polyphenolic compound processed by several plants and found in certain fruits, including peanuts, berries, and grapes [119]. At the beginning, interest for RSV has been linked to epidemiological studies aimed at clarifying cardioprotection effects of red wine [120]. Subsequently, in numerous investigations performed in vitro and in animal models, it has been established that RSV mainly (i) regulates high blood pressure and ameliorates vascular biology [121]; (ii) counteracts NAFLD progression [122]; (iii) improves insulin sensitivity [123]; (iv) promotes adipose tissue remodeling [124]; and (v) modifies gut microbiota composition [125], acting on the same mechanism activating by CR.

RSV reduces high blood pressure, enhancing the AMPK-SIRT1 axis [126]. Moreover, RSV increases nitric oxide and simultaneously decreases ROS production $[127,128]$ (Table 2).

In hepatocytes affected by steatosis or in NALFD mice models, RSV thwarts hepatic steatosis, dropping hepatic lipid accumulation and inflammation by AMPK/SIRT1 activation [129-131]. Teng et al. have observed that in steatotic hepatocytes (HepG2 cell model), RSV treatment decreases triglyceride accumulation by modulating the AMPK/SIRT1 signaling pathway. In addition, in mice affected by NAFLD, RSV not only counteracts liver steatosis but also recovers hepatic insulin sensitivity [132] (Table 2). 
Table 2. Resveratrol as a CR-related nutrient (N.D. = no date, $\uparrow$ increase $/$ improvement, $\downarrow$ decrease/worsening).

\begin{tabular}{|c|c|c|c|}
\hline Type of Studies & $\begin{array}{l}\text { Tissue Molecular } \\
\text { Mechanisms }\end{array}$ & Effects & References \\
\hline In vivo (obese rats) & 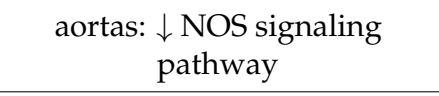 & $\begin{array}{l}\downarrow \text { endothelial dysfunction and } \\
\text { vascular insulin resistance }\end{array}$ & Akar et al. [126] \\
\hline In vivo (hypertensive rats) & $\begin{array}{l}\text { rostral ventrolateral medulla } \\
\text { (RVLM): } \uparrow \text { AMPK activation }\end{array}$ & $\begin{array}{c}\downarrow \text { blood pressure and ROS } \\
\text { generation } \\
\uparrow \text { ERK1/2-RSK-nNOS pathway }\end{array}$ & Cheng et al. [127] \\
\hline In vivo (hypertensive rats) & $\begin{array}{c}\text { endothelium: } \uparrow \\
\text { superoxide dismutase activity }\end{array}$ & $\begin{array}{l}\downarrow \text { oxidative stress induced by } \\
\text { altered nitrite/nitrate levels } \\
\downarrow \text { development of hypertension }\end{array}$ & Bhatt et al. [128] \\
\hline In vivo (obese rats) & $\begin{array}{c}\text { liver: } \uparrow \text { activation of SIRT1 } \\
\text { signaling } \uparrow \\
\text { autophagy }\end{array}$ & $\begin{array}{l}\downarrow \text { endoplasmic reticulum stress } \\
\downarrow \text { hepatic lipid accumulation }\end{array}$ & Ding et al. [129] \\
\hline In vitro and in vivo (obese rats) & $\begin{array}{l}\text { Liver and hepatocytes treated } \\
\text { with high } \\
\text { concentration of glucose and } \\
\text { insulin: } \uparrow \text { AMPK activation }\end{array}$ & $\begin{array}{c}\downarrow \text { triacylglycerol (TG) } \\
\text { accumulation } \\
\uparrow \text { improved insulin resistance }\end{array}$ & Shang et al. [130] \\
\hline In vitro and in vivo (obese rats) & $\begin{array}{c}\text { Liver: } \uparrow \text { PKA/AMPK/PPAR } \alpha \\
\text { signaling pathway } \\
\text { activation }\end{array}$ & $\begin{array}{l}\downarrow \text { redox homeostasis and lipid } \\
\text { accumulation }\end{array}$ & Huang et al. [131] \\
\hline $\begin{array}{l}\text { In vitro and in vivo (NAFLD mice } \\
\text { model) }\end{array}$ & $\begin{array}{l}\text { Liver: } \\
\uparrow \text { AMPK/SIRT1/FAS/ } \\
\text { SREBP1c signaling } \\
\text { pathway activation }\end{array}$ & $\begin{array}{l}\downarrow \text { triglyceride accumulation } \\
\uparrow \text { improved insulin resistance }\end{array}$ & Teng et al. [132] \\
\hline In vitro & $\begin{array}{c}\text { 3T3 L1 adipocytes: } \\
\uparrow \text { SIRT1-AMPK signalling } \\
\text { activation } \\
\uparrow \text { FOXO nuclear translocation }\end{array}$ & $\begin{array}{c}\uparrow \text { glucose metabolism } \\
\uparrow \text { improved insulin resistance }\end{array}$ & Chen et al. [133] \\
\hline In vitro & $\begin{array}{l}\text { Skeletal muscle cells: } \\
\uparrow \text { AMPK activation }\end{array}$ & $\begin{array}{c}\uparrow \text { GLUT4 translocation } \\
\uparrow \text { improved insulin resistance }\end{array}$ & $\begin{array}{l}\text { Vlavcheski et al. } \\
\text { [134] }\end{array}$ \\
\hline In vitro and in vivo (obese mice) & $\begin{array}{l}\text { Liver and hepatocytes: } \\
\uparrow \text { PI3K-Akt signalling } \\
\text { activation }\end{array}$ & $\uparrow$ improved insulin resistance & Shu et al. [135] \\
\hline $\begin{array}{c}\text { In vivo (obese mice) and human } \\
\text { study (obese volunteers aged 30-55 } \\
\text { years) }\end{array}$ & $\begin{array}{l}\text { Adipose tissue: } \uparrow \text { SIRT } \\
\text { signalling activation }\end{array}$ & $\begin{array}{l}\uparrow \text { improved glycemic and lipid } \\
\text { profiles } \\
\uparrow \text { expression of genes (UCP1, } \\
\text { PRDM16, PGC } 1 \alpha \text { ) involved in } \\
\text { adipose tissue thermogenesis }\end{array}$ & Andrade et al. [136] \\
\hline In vivo (obese female mice) & $\begin{array}{c}\text { Adipose tissue: } \uparrow \text { AMPK } \\
\text { activation }\end{array}$ & $\begin{array}{l}\uparrow \text { brown-like adipocyte formation } \\
\text { in inguinal white adipose tissue }\end{array}$ & Wang et al. [137] \\
\hline In vivo (obese mice) & $\begin{array}{l}\text { Adipose tissue and gut: } \\
\uparrow \text { gut microbiota-bile } \\
\text { acid-TGR5/UCP1 pathway }\end{array}$ & $\begin{array}{c}\uparrow \text { brown adipose tissue activation } \\
\text { and white adipose tissue } \\
\text { browning }\end{array}$ & Hui et al. [138] \\
\hline In vivo (obese mice) & $\begin{array}{l}\text { Adipose tissue and gut: } \\
\uparrow \text { SIRT1 signalling activation }\end{array}$ & $\begin{array}{c}\downarrow \text { fat accumulation } \\
\downarrow \text { gut microbiota dysbiosis } \\
\uparrow \text { white adipose tissue browning }\end{array}$ & Liao et al. [139] \\
\hline In vivo (obese mice) & $\begin{array}{l}\text { Adipose tissue: } \uparrow \\
\text { antioxidative mitochondrial } \\
\text { pathway }\end{array}$ & $\begin{array}{c}\downarrow \text { body weight gain } \\
\downarrow \text { oxidative and inflammatory } \\
\text { condition } \\
\downarrow \text { gut microbiota alterations }\end{array}$ & Campbell et al. [140] \\
\hline In vivo (atherosclerotic mice model) & $\begin{array}{l}\downarrow \text { enterohepatic farnesoid } X \\
\text { receptor-fibroblast growth } \\
\text { factor } 15 \text { axis }\end{array}$ & $\begin{array}{c}\uparrow \text { gut microbiota remodeling } \\
\uparrow \text { hepatic bile acid neosynthesis } \\
\downarrow \text { TMAO production }\end{array}$ & Chen et al. [141] \\
\hline
\end{tabular}


RSV improves insulin sensitivity not only in liver but also in adipose tissue and in skeletal muscle. Chen et al. have observed how through acting on the SIRT1/AMPK axis, RSV improves the insulin pathway and glucose translocation in adipocytes [133]. In insulin-resistant skeletal muscle cells, AMPK activation by RSV increases insulin-mediated GLUT4 translocation [134]. Finally, Shu et al. have proved through in vitro and in vivo models of insulin resistance that RSV increases microRNA (miRNA) mmu-miR-363-3p levels and consequently improved AKT signaling, ameliorating metabolic condition [135] (Table 2).

Adipose tissue remodeling represents a further common action between RSV and CR. RSV-treated obese rats or mice are characterized by a significant reduced adipose tissue mass and an increased thermogenesis associated with high expression of SIRT1 and UCP1 [136]. In addition, mice fed a high-fat diet with $0.1 \%$ RSV have shown a significant increase of AMPK activation and an upregulation of brown adipocyte markers, including UCP1 [137]. Finally, Hui et al. have demonstrated that 10 weeks of RSV treatment promotes glucose metabolism and the adipose browning process not only by AMPK activation but also by gut microbiota composition modification, as demonstrated by antibiotic treatment. The depletion of gut microbiota, caused by antibiotics, partially abolishes RSV effects [138]. Data obtained by this work strengthen accumulating evidence that reveals how RSV modifying gut microbiota leads to weight loss, insulin sensitivity improvement, and white adipose tissue conversion in beige adipose tissue [139]. In addition, RSV action on gut mitigates oxidative stress and inflammation [140]. Furthermore, current studies suggest that RSV, via gut microbiota remodeling, attenuates the atherosclerosis process and increases hepatic bile acid neosynthesis, downregulating the enterohepatic farnesoid $X$ receptor-fibroblast growth factor 15 axis [141]. In addition, RSV counteracts atherosclerosis onset action on endothelial dysfunction, as is well known. RSV's endothelial positive effects are mediated by AMPK/SIRT1/eNOS signaling cascade in a similar manner to that of CR [142].

Unfortunately, the efficacy of RSV supplementation as a CR mimetic is not yet confirmed by clinical studies: a small number of clinical trials have been performed, and the results are discordant $[143,144]$. It is important to remember that RSV bioavailability is very low, and several authors have observed how different RSV doses are correlated with different actions $[145,146]$. Identifying RSV effective dose and pharmacokinetics probably represents the crucial question to solve [147].

\section{From Caloric Restriction to CR-Related Nutrients: Quercetin}

Quercetin $(\mathrm{QE})$, an important member of flavonoids principally found in elderberries, onions, cranberries, apples, and in other fruits and vegetables is one of well-known dietary antioxidant compounds [148]. As BRR and RSV in vitro and in vivo studies show, QE ameliorates hypertension, heart failure condition [149], obesity, diabetes, inflammation state [150], and gut dysbiosis [151].

Accumulating lines of evidence indicate that $\mathrm{QE}$ plays an important anti-hypertensive action mainly through increasing nitric oxide (NO) production, decreasing oxidative stress, and activating the AMPK signaling pathway, as observed by Calabrò et al. in hypertensive rats [152]. In addition, Kim et al., using an in vitro model, have observed that $Q E$ activating AMPK signaling attenuates vascular smooth muscle cells contraction [153]. Moreover, QE treatment improves cardiac hypertrophy, which is a pathological cardiac modification that usually leads the onset of heart failure [154-156]. In an in vitro model of rat cardiomyocytes, QE action is mediated by PPAR $\gamma$ [154], while Guo et al. have proven that QE counteracts hypoxic damages and prevents cardiomyocytes apoptosis by AMPK-SIRT1 axis activation [156]. Then, QE also activates the same molecular mediators as CR.

As previous reported, a hyperglycemic-induced oxidative microenvironment is a crucial cause of therapeutically ineffective cardioprotection interventions. Roslan et al. have observed that QE treatment alleviates metabolic alteration, increasing insulin levels and contemporarily decreasing cardiac inflammatory and oxidative stress markers [157]. 
QE action on inflammatory mediators has been also observed in the liver of obese/diabetes mice $[158,159]$. Zhu et al. have studied QE action in an in vitro and in vivo model, demonstrating that QE reduces hepatic triglyceride and promotes lipophagy [160]. Moreover, different works have reported that isoquercetin, a QE derivative, activates AMPK alleviating hepatic lipid accumulation [161,162]. In addition, in skeletal muscle, QE enhances AMPK/SIRT1 signaling cascade and promotes glucose uptake [163-165]. Moreover, other data have revealed that QE stimuli regulate IRSs phosphorylation, alleviating insulin resistance and promoting pro-oxidant/antioxidant enzymes balance [166,167].

As CR, QE influences adipose tissue. As studied by Forney et al., QE inhibits lipid accumulation, decreasing adipose tissue mass [168]. In addition, the adipose-induced inflammation process is decreased by QE. Researchers have not completely clarified the molecular mechanisms used by QE to counteract adipose inflammation; probably, QE activates MAPK kinases cascade and downregulates NOX enzymes [169,170]. Recently, different groups have observed that $\mathrm{QE}$ improves the inflammasome response, ameliorating gut dysbiosis [171]. In addition, in this case, QE action on the gut is associated with a reduced atherosclerotic process [172,173]. In detail, Zhang et al. have observed that QE treatment in obese diabetic rats improves the lipid metabolism and reduces the number of atherosclerotic lesions, enhancing the activity of antioxidant enzymes in the carotid artery. They demonstrated, using a specific AMPK inhibitor (compound-C), that QE mitigates atherosclerotic damages, activating the AMPK/SIRT1/NF- $\mathrm{KB}$ signaling pathway [174].

Finally, it is important to remember that not only QE but also its metabolites, such as rutin, play a positive role in diabetes and cardiovascular diseases [149,175]. Taken together, these results indicate that $\mathrm{QE}$ promotes cardiometabolic health, activating several common molecular targets of CR (Table 3).

Table 3. Quercetin as a CR-related nutrient ( $\uparrow$ increase/improvement, $\downarrow$ decrease/worsening).

\begin{tabular}{|c|c|c|c|}
\hline Type of Studies & Tissue Molecular Mechanisms & Effects & References \\
\hline In vivo (rats) & $\begin{array}{c}\text { Heart: } \downarrow \text { NADPH oxidase } \\
\text { (NOX)-dependent superoxide } \\
\text { anion production }\end{array}$ & $\begin{array}{c}\downarrow \text { blood pressure } \\
\uparrow \text { activities of oxidant detoxifying } \\
\text { enzymes }\end{array}$ & Calabrò et al. [152] \\
\hline In vitro & $\begin{array}{l}\text { vascular smooth muscle cells: } \uparrow \\
\text { AMPK activation }\end{array}$ & $\begin{array}{c}\downarrow \text { myosin light chain kinase (MLCK) } \\
\text { expression } \\
\downarrow \text { phosphorylated myosin light chain }\end{array}$ & Kim et al. [153] \\
\hline In vitro and in vivo (hypertensive rats) & $\begin{array}{c}\text { Heart and hypertrophic } \\
\text { cardiomyocytes: } \\
\uparrow \text { PPAR- } \gamma \text { expression } \\
\downarrow \text { AP-1 signaling pathway }\end{array}$ & $\begin{array}{l}\downarrow \text { blood pressure } \\
\downarrow \text { reduced the ratio of left ventricular } \\
\text { to body weight }\end{array}$ & Yan et al. [154] \\
\hline In vivo (hypercholesterolemic mice) & Blood sample & $\begin{array}{c}\downarrow \text { total cholesterol and very } \\
\text { low-density lipoprotein } \\
\downarrow \text { maladaptive myocardial remodeling }\end{array}$ & Ulasova et al. [155] \\
\hline In vitro & $\begin{array}{c}\text { Cardiomyocytes } \uparrow \text { SIRT1-AMPK } \\
\text { signaling pathway activation after } \\
\text { hypoxia damages }\end{array}$ & $\downarrow$ apoptosis & Guo et al. [156] \\
\hline In vivo (diabetic rats) & $\begin{array}{l}\text { Heart: } \uparrow \text { activity level of cardiac } \\
\text { anti-oxidative enzymes }\end{array}$ & $\begin{array}{c}\downarrow \text { cardiac injury } \\
\uparrow \text { hemodynamic parameters } \\
\uparrow \text { metabolic profile }\end{array}$ & Roslan et al. [157] \\
\hline In vivo (obese diabetic mice) & $\begin{array}{l}\text { Liver: } \downarrow \text { p } 65 / \text { NF- } \kappa \text { B and } \\
\text { ERK1-2/MAPK signaling } \\
\text { pathways }\end{array}$ & $\begin{array}{c}\downarrow \text { body weight gain, oxidative state, } \\
\text { and liver injury } \\
\uparrow \text { metabolic profile }\end{array}$ & Zhang et al. [158] \\
\hline In vivo (obese diabetic mice) & $\begin{array}{l}\text { Liver: } \uparrow \text { activity level of hepatic } \\
\text { anti-oxidative enzymes }\end{array}$ & $\begin{array}{l}\uparrow \text { metabolic profile and adiponectin } \\
\text { serum level } \\
\downarrow \text { oxidative state and dyslipidaemia }\end{array}$ & Jeong et al. [159] \\
\hline In vitro and in vivo (obese rats) & $\begin{array}{c}\text { Liver and hepatocytes: } \uparrow \\
\text { IRE1a/XBP1s pathway signaling } \\
\text { activation } \\
\downarrow \text { lipophagy }\end{array}$ & $\downarrow$ hepatic steatosis & Zhu et al. [160] \\
\hline
\end{tabular}


Table 3. Cont.

\begin{tabular}{|c|c|c|c|}
\hline Type of Studies & Tissue Molecular Mechanisms & Effects & References \\
\hline In vivo (obese rats) & $\begin{array}{l}\text { Liver: } \uparrow \text { AMPK activation } \\
\quad \downarrow \text { TGF- } \beta \text { signalling }\end{array}$ & $\begin{array}{l}\downarrow \text { lipid accumulation } \\
\downarrow \text { inflammation state } \\
\downarrow \text { oxidative stress }\end{array}$ & Qin et al. [161] \\
\hline In vitro & $\begin{array}{c}\text { Rat hepatoma cells (H4IIE): } \uparrow \\
\text { AMPK activation and AdipoR1 } \\
\quad \text { expression } \\
\downarrow \text { SREBP- } 1 \text { and FAS expression }\end{array}$ & $\downarrow$ lipid accumulation & Zhou et al. [162] \\
\hline In vitro & $\begin{array}{c}\text { Skeletal muscle cells, murine and } \\
\text { human hepatocytes: } \uparrow \text { AMPK } \\
\text { activation } \\
\uparrow \text { GLUT4 translocation }\end{array}$ & $\uparrow$ glucose metabolism & Eid et al. [163] \\
\hline In vitro & $\begin{array}{l}\text { Skeletal muscle cells: } \\
\uparrow \text { AMPK activation }\end{array}$ & $\begin{array}{c}\downarrow \text { insulin-mediated glucose disposal in } \\
\text { normal condition } \\
\uparrow \text { insulin resistance correlated to } \\
\text { inflammatory condition }\end{array}$ & Liu et al. [164] \\
\hline In vivo (obese diabetic rats) & $\begin{array}{l}\text { Liver: } \uparrow \text { SIRT1 expression } \\
\quad \uparrow \text { AKT activation }\end{array}$ & $\begin{array}{c}\uparrow \text { glucose and lipid metabolism } \\
\downarrow \text { hepatic histomorphological injury }\end{array}$ & Peng et al. [165] \\
\hline In vitro & $\begin{array}{c}\text { Endothelial cells: } \\
\uparrow \text { IRS1/PI3K signaling pathway } \\
\text { activation } \\
\uparrow \text { Akt/eNOS signaling pathway } \\
\text { activation }\end{array}$ & $\begin{array}{l}\downarrow \text { inflammation state } \\
\downarrow \text { oxidative stress }\end{array}$ & Guo et al. [166] \\
\hline In vitro & $\begin{array}{l}\text { Hepatocytes: } \downarrow \text { SREBP-1c and } \\
\text { fatty acid synthase FAS }\end{array}$ & $\downarrow$ hepatic lipid accumulation & Li et al. [167] \\
\hline In vivo (obese mice) & $\begin{array}{c}\text { Adipose tissue: } \downarrow \text { inflammatory } \\
\text { mediators }\end{array}$ & $\begin{array}{l}\downarrow \text { adipocyte size and number in } \\
\text { subcutaneous and visceral white } \\
\text { adipose tissue }\end{array}$ & Forney et al. [168] \\
\hline $\begin{array}{l}\text { In vitro and in vivo (zebrafish and } \\
\text { mouse) }\end{array}$ & $\begin{array}{c}\text { Adipocytes and macrophages: } \\
\downarrow \text { adipogenic factors (C/EBPs and } \\
\text { PPAR } \gamma) \\
\downarrow \text { MAPK signaling pathway } \\
\downarrow \text { inflammatory cytokines }\end{array}$ & $\begin{array}{c}\quad \downarrow \text { weight gain } \\
\downarrow \text { lipid accumulation } \\
\downarrow \text { inflammatory state }\end{array}$ & Seo et al. [169] \\
\hline In vivo (obese mice) & $\begin{array}{l}\text { Adipose tissue: } \downarrow \text { NFkB activity } \\
\uparrow \text { mitochondrial function }\end{array}$ & $\downarrow$ inflammatory state in adipose tissue & Kobori et al. [170] \\
\hline In vivo (obese mice) & $\begin{array}{l}\text { Gut-liver: } \downarrow \text { (TLR-4)-NF-кB } \\
\text { signaling pathway }\end{array}$ & $\begin{array}{c}\downarrow \text { intrahepatic lipid accumulation } \\
\downarrow \text { insulin resistance } \\
\downarrow \text { gut dysbiosis }\end{array}$ & Porras et al. [171] \\
\hline In vivo (obese mice) & aortic sinus and gut microbiota & $\begin{array}{l}\downarrow \text { atherosclerotic lesions and gut } \\
\text { dysbiosis }\end{array}$ & Nie et al. [172] \\
\hline In vivo (obese mice) & aortic sinus & $\begin{array}{l}\downarrow \text { atherosclerotic lesions } \\
\downarrow \text { lipid accumulation } \\
\uparrow \text { microbiome diversity }\end{array}$ & Wu et al. [173] \\
\hline In vivo (obese diabetic rats) & $\begin{array}{c}\text { carotid artery: } \\
\uparrow \text { AMPK/SIRT1 activation } \\
\downarrow \text { NF-kB signaling pathway }\end{array}$ & $\begin{array}{c}\uparrow \text { lipid profile } \\
\downarrow \text { atherosclerotic lesions } \\
\downarrow \text { oxidative stress }\end{array}$ & Zhang et al. [174] \\
\hline
\end{tabular}

However, the data collected about the effects of QE are partially conflicting, and as with RVS, pharmacokinetics is the main problem to solve [149-151,176].

\section{From Caloric Restriction to CR-Related Nutrients: L-Carnitine}

In recent years, several works have shed new light on L-carnitine (LC), which is the biologically active form of dietary nutrient carnitine found principally in red meat and eggs [177].

Over the past decade, several research groups have demonstrated a positive correlation between high atherosclerosis risk and trimethylamine-N-oxide (TMAO), which is produced by gut bacterial metabolism of betaine and above all of choline and LC [178]. Several data reported in the literature have shown that TMAO activates the NF-KB pathway, 
enhancing the production of inflammatory cytokines and chemokines besides increasing ROS levels [179-181]. Moreover, TMAO is associated with an unbalanced regulation of cholesterol production and, in detail, with an impaired reverse cholesterol transport to and from the liver and small intestine [182-184]. Numerous data have indicated that LC supplementation accelerates TMAO-induced atherosclerosis in mice models $[185,186]$. Recently, Bordoni et al. observed that in aged women, LC intake and consequently TMAO production cause epigenetic alterations of mitochondrial DNA in platelets, contributing to atherosclerosis development [187]. Recently, epidemiological studies have established that only concomitant high levels of plasma LC and TMAO are associated with an increased risk of CVD development [188,189].

This simple overview would suggest limiting carnitine intake, but several other data indicate that LC plays, through AMPK signaling, an important cardioprotective role, counteracting mitochondrial dysfunction and aberrant ROS synthesis.

LC supplementation ameliorates left ventricular dysfunction, decreasing ROS production and improving glucose and fat acid metabolism [190]. Moreover, several authors have proven that LC stimuli mitigate ischemia-reperfusion-induced damages, activating the principal cellular mechanisms involved in anti-oxidative and anti-apoptotic mechanisms, mainly reperfusion injury salvage kinase (RISK) and survivor-activating factor enhancement (SAFE) signaling pathways [191-193]. Additionally, our group recently demonstrated the cardioprotective LC action in an in vitro model of hyperglycemic cardiomyocytes [194], and above all, we have proven that LC effects are mediated by AMPK. Then, LC supplementation could be used in patients affected by chronic heart disease, such as left ventricular dysfunction. Moreover, in acute conditions, such as in myocardial infarction, LC could mitigate abnormal oxidative stress condition and enhance cardiomyocytes survival. Animal studies and preliminary clinical studies seem to confirm this hypothesis [195-198]. It is important to note that these first trials suggest that LC improves antioxidative cellular defense, in particular the NRF2 pathway [198].

Different results have shown that LC implementation has not only antioxidant action but also hypoglycemic effects in diabetic rats [199]. In addition, several works have reported that LC ameliorates NAFLD condition decreases lipid accumulation and prevents NAFLD-induced heart dysfunction. The possible mechanism of this LC action is related to its ability to activate redox-signaling pathways, promoting mitochondrial activities and AMPK signaling $[200,201]$. In confirmation of the AMPK role in LC action, our group recently demonstrated that LC supplementation mitigates liver steatosis induced by fructose, activating AMPK and consequently increasing anti-oxidative cellular response [202]. Similarly, Sayed-Ahmed et al. have observed that LC supplementation mitigates chemotherapy-induced cardiotoxicity, increasing AMPK signaling [203].

As reported above, LC intake is associated with TMAO production, and this is a crucial limit on LC use in the treatment of cardiometabolic pathologies. Zhao et al. have demonstrated, in a mouse model of atherosclerosis ( $\mathrm{ApoE}^{-/-}$mice), that subcutaneous LC administration, bypassing intestinal-liver TMAO formation, does not aggravate the atherosclerosis process [204]. Then, it is hypothesized that the synergic use of LC and drugs capable of inhibiting TMAO synthesis could represent the ideal solution. TMAO is primary produced following an oxidative reaction of microbial metabolite trimethylamine (TMA) catalyzed by hepatic flavin monooxygenase 3 (FMO3) [183]. FMO3 knockout mice and subjects with a genetic defect in FMO3, despite having higher levels of TMA, are not characterized by a higher risk of atherosclerosis [205,206]. Then, modulating FMO3 expression, it is possible to modify TMAO production. Different studies have demonstrated that enterohepatic farnesoid X Receptor (FXR), a nuclear receptor, enhances FMO3 expression [206], and natural compounds (RSV) [141,207] or chemical antagonists of FXR (guggulsterone) [208] positively modulate the TMAO/TMA ratio. Therefore, further studies are needed to explore this therapeutical opportunity to resolve the TMAO "problem" and to use LC supplementation as mimic caloric restriction (Table 4). 
Table 4. L-carnitine as a CR-related nutrient ( $\uparrow$ increase/improvement, $\downarrow$ decrease/ worsening).

\begin{tabular}{|c|c|c|c|}
\hline Type of Studies & $\begin{array}{l}\text { Tissue Molecular } \\
\text { Mechanisms }\end{array}$ & Effects & References \\
\hline $\begin{array}{c}\text { In vivo (rats fed with choline } \\
\text { deficient diet) }\end{array}$ & Heart & $\begin{array}{c}\uparrow \text { cardiac function } \\
\downarrow \text { cardiac inflammation }\end{array}$ & Strilakou et al. [190] \\
\hline In vivo (hypertensive rats) & Heart & $\begin{array}{c}\uparrow \text { cardiac function } \\
\downarrow \text { blood pressure } \\
\downarrow \text { cardiac inflammation and } \\
\text { fibrotic process }\end{array}$ & O'Brien et al. [191] \\
\hline $\begin{array}{c}\text { Human study (patients } \\
\text { undergoing valve replacement) }\end{array}$ & $\begin{array}{l}\text { Heart: } \uparrow \text { Bcl-2 anti-apoptotic } \\
\quad \text { factor } \\
\downarrow \text { Bax pro-apoptotic factor }\end{array}$ & $\downarrow$ cardiac cells apoptosis & Li et al. [192] \\
\hline In vivo (mice with I/R injury) & $\begin{array}{c}\text { Heart: } \uparrow \text { PI3K/Akt activation } \\
\uparrow \text { Bcl-2 anti-apoptotic factor } \\
\downarrow \text { Bax pro-apoptotic factor }\end{array}$ & $\begin{array}{l}\uparrow \text { myocardial contractile } \\
\quad \text { function } \\
\downarrow \text { myocardial apoptosis }\end{array}$ & Xue et al. [193] \\
\hline In vitro & $\begin{array}{c}\text { Cardiac cells (H9c2) grown in } \\
\text { hyperglycemic condition: } \uparrow \\
\text { AMPK and STAT3 activation } \\
\uparrow \text { anti-oxidative factors }\end{array}$ & $\downarrow$ oxidative stress & Vacante et al. [194] \\
\hline $\begin{array}{c}\text { In vivo (Sprague-Dawley rats } \\
\text { with heatstroke-induced cardiac } \\
\text { injury) }\end{array}$ & Heart: $\uparrow$ anti-oxidative factors & $\begin{array}{c}\downarrow \text { inflammatory response } \\
\downarrow \text { oxidative stress } \\
\downarrow \text { cardiomyocytes apoptosis }\end{array}$ & Wang et al. [195] \\
\hline $\begin{array}{l}\text { In vitro and in vivo (rats with } \mathrm{I} / \mathrm{R} \\
\text { injury) }\end{array}$ & $\begin{array}{c}\text { Heart and cardiomyocytes: } \downarrow \\
\text { nuclear transcription-related } \\
\text { factor } 2 / \text { heme oxygenase- } 1 \\
(\mathrm{Nrf} 2 / \mathrm{HO}-1)\end{array}$ & $\begin{array}{c}\downarrow \text { oxidative stress } \\
\downarrow \text { cardiomyocytes apoptosis }\end{array}$ & Zhao et al. [196] \\
\hline Human study (meta-analysis) & $\begin{array}{c}\downarrow \text { serum inflammatory } \\
\text { mediators } \\
\uparrow \text { superoxide dismutase level }\end{array}$ & $\begin{array}{c}\downarrow \text { inflammatory cytokines } \\
\uparrow \text { antioxidant mitochondrial } \\
\text { enzymes }\end{array}$ & Fathizadeh et al. [197] \\
\hline Human study & 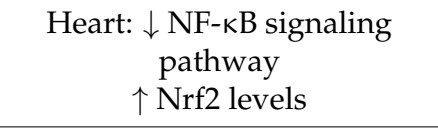 & $\begin{array}{c}\downarrow \text { inflammatory cytokines } \\
\uparrow \text { antioxidant mitochondrial } \\
\text { enzymes }\end{array}$ & Li et al. [198] \\
\hline In vivo (diabetic rats) & $\begin{array}{l}\text { Skeletal muscle: } \uparrow \\
\text { anti-oxidative factors }\end{array}$ & $\begin{array}{c}\uparrow \text { insulin sensitivity index } \\
\uparrow \text { metabolic profile } \\
\uparrow \text { contractile properties }\end{array}$ & Samir et al. [199] \\
\hline In vivo (NAFLD model mice) & $\begin{array}{c}\text { Heart and liver: } \downarrow \text { hepatic } \\
\text { NF-kB signaling } \\
\uparrow \text { hepatic PPARy } \\
\downarrow \text { myocardial ERK/STAT3 } \\
\text { pathway }\end{array}$ & $\begin{array}{c}\downarrow \text { hepatic steatosis } \\
\downarrow \text { hepatic fibrosis } \\
\downarrow \text { hepatic and myocardial } \\
\text { oxidative stress }\end{array}$ & Mollica et al. [200] \\
\hline $\begin{array}{c}\text { Human study (meta-analysis in } \\
\text { patients with NAFLD) }\end{array}$ & Liver & $\begin{array}{c}\uparrow \text { hepatic function } \\
\downarrow \text { insulin resistance condition }\end{array}$ & Abolfathi et al. [201] \\
\hline In vitro & $\begin{array}{l}\text { Hepatic cells treated with } \\
\text { fructose: } \\
\uparrow \text { AMPK activation }\end{array}$ & $\begin{array}{c}\downarrow \text { lipid accumulation } \\
\downarrow \text { oxidative stress } \\
\uparrow \text { mitochondrial function }\end{array}$ & Montesano et al. [202] \\
\hline $\begin{array}{l}\text { In vivo (rats treated with } \\
\text { sunitinib) }\end{array}$ & Heart: $\uparrow$ AMPK activation & $\begin{array}{c}\downarrow \text { induced-sunitinib } \\
\text { cardiotoxicity } \\
\uparrow \text { mitochondrial transport of } \\
\text { LCFA }\end{array}$ & Sayed-Ahmed et al. [203] \\
\hline
\end{tabular}

\section{From Caloric Restriction to CR-Related Nutrients: Bioavailability and Pharmacokinetics}

As mentioned above, while obtained data from in vitro and in vivo studies are very encouraging for a possible use of BBR, RSV, and QE and LC in management of diabetes 
and cardiovascular diseases complications, clinical data are partly controversial. Bioavailability, dose, and pharmacokinetics are fundamental aspects that have yet to be completely clarified, and this limits the use of these nutraceutical compounds [147,176].

To solve these problems, some authors have proposed the use of synthesized products having similar proprieties of nutraceuticals. SRT2104, a SIRT1 activator as RSV, is one of the best known of these compounds [209-211]. Unfortunately, even using SRT2104, the results of small clinical studies are partly conflicting. Baksi et al. performed, for 28 days, a phase II, randomized, double-blinded study of SRT2104 in diabetics subjects. They used different doses of SRT2104 but did not observe a positive significant impact on metabolic parameters (no effect on glycemia and $\mathrm{HbA1c}$, modest action on lipid), but the results of their study shown above were characterized by a highly variable response [209]. Meanwhile, Noh et al., studying in the same manner of 28 days of SRT2104 treatment in diabetic patients, observed significant weight loss and an improvement of glycemic control but neutral impacts on endothelial and fibrinolytic function [210]. This last finding is in contradiction with the results previously obtained by the same research group in diabetic patients and healthy smokers [211]. This brief overview points out the main problems associated with the development of synthetic compounds capable of mimicking RSV action: the small size of analyzed groups and subjects' variability constitute an important limitation to clarifying the action and the pharmacokinetics of SRT2104 and other similar innovative drugs [212].

Similarly, to improve BBR bioavailability, many derivatives of BBR were synthesized. For example, dihydroberberine (dhBBR) and 8,8-dimethyldihydroberberine (Di-MeBBR) reduce the atherosclerotic process in $\mathrm{ApoE}^{-/-}$mice [213]. Wang et al. have designed and synthesized four series of BBR derivatives that have potent hypoglycemic activity due to the AMPK activation pathway [214]. However, even then, further investigations should be performed to clarify molecular mechanisms.

To strengthen the effects of CR mimetics compounds, different research groups are investigating the synergic use of drug and food CR mimetics or two CR mimetics, obtained encouraging results [215-218]. However, even these studies are often contradictory.

So perhaps a possible interesting solution could be represented by the development of the nutritional strategies based on new $\mathrm{CR}$ regimens, i.e., intermittent fasting regimes and time-restricted feeding, and CR mimetics. An intermittent fasting regime is characterized by alternate periods of fasting with recurring periods, usually 1 or 2 fasting days per week or on alternative days [219]. A time-restricted program requires that food consumption be limited to certain hours of the day [220]. These regimes seem to have a similar effect to CR but do not require ongoing commitment from patients; therefore, these diet strategies could be used to overcome CR problems linked to patients' adhesion, and food CR mimetics could be used to strengthen their effectiveness.

\section{Conclusions}

$\mathrm{CR}$, an emerging restrictive nutritional approach, enhances healthspan and lifespan through ameliorating metabolic and cardiovascular functions and decreasing oxidative and low-grade inflammation states. The AMPK/SIRT1 signaling cascade is the key molecular pathway influenced by CR. AMPK/SIRT1 activation is associated with (i) increased mitochondrial and endothelial function, (ii) improved gut dysbiosis, (iii) ameliorated muscle and hepatic insulin signaling, (iv) and increased adipose tissues remodeling. However, for most subjects, performing this nutritional regime is impossible. Caloric restriction is not only a diet, but an important change of lifestyle, and it is a challenge for many patients affected by T2DM and/or CVD who usually are unable to observe these restriction conditions for a long period.

For this reason, different research groups have identified and studied different nutritional compounds capable of mimicking caloric restriction effects. Berberine, resveratrol, and quercetin are the best-known CR mimetics characterized by their action on AMPK/SIRT1 signaling. Moreover, recent data have shown that LC could be used in the management of diabetes and cardiovascular diseases as well. 
Then, the consumption of these nutraceuticals or innovative functional food enriched with these nutritional components could represent an important nutritional strategy in T2DM and CVD management (Figure 3).

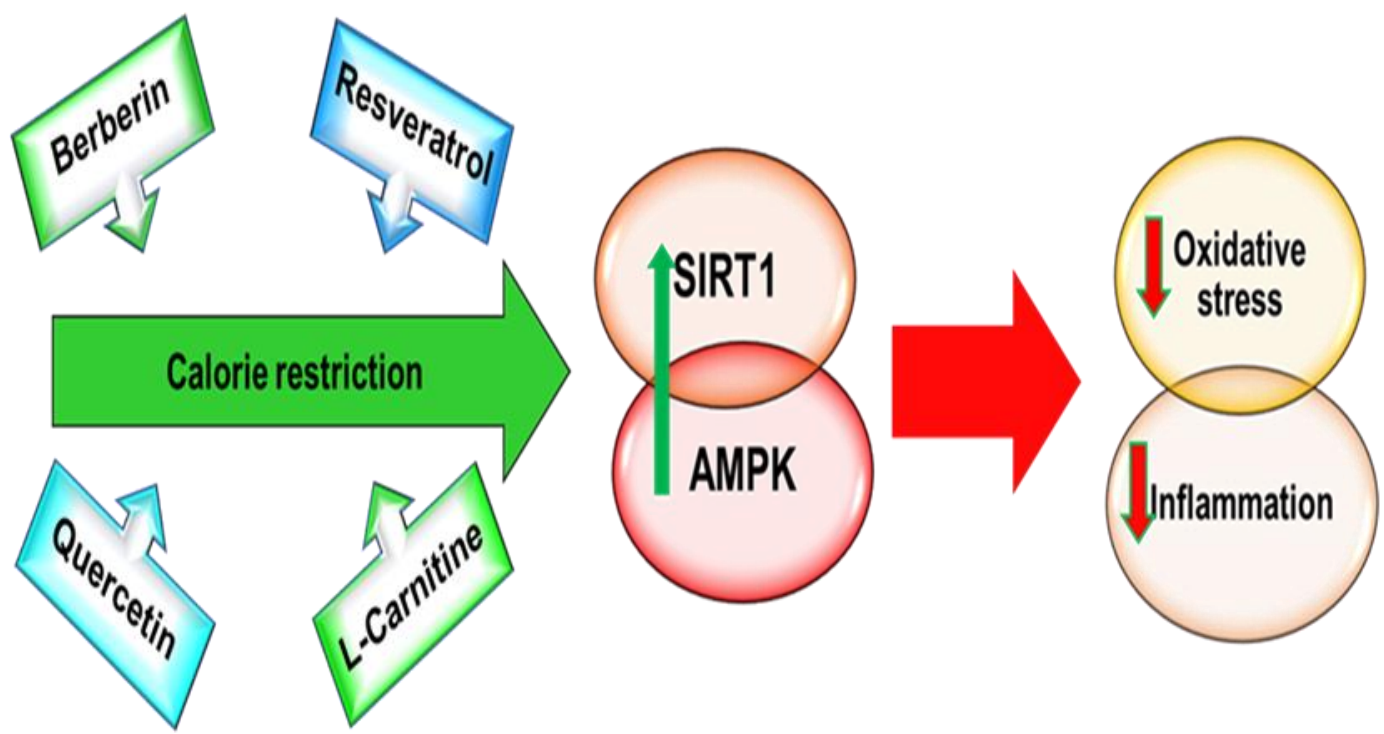

Figure 3. CR-related nutrients. Calorie restriction through AMPK/SIRT activation reduces the risk of developing T2DM and CVD. Berberin, resveratrol, quercetin and L-carnitine are also capable of activating AMPK/SIRT1 and therefore could be used as CR mimetics to preserve a healthy cardiometabolic state.

In addition, it is important to note that AMPK is the key molecular regulator of exercise action [221]. Moreover, some researcher groups, including us, have demonstrated how CR mimetics, for instance RSV and LC, enhance skeletal muscle differentiation [146,222]. Therefore, it appears essential to study the combined effect of nutritional interventions based on CR mimetics and exercise. In the future, identifying nutritional agents able to improve cardiometabolic state should be evaluated in associated with lifestyle therapeutic interventions (diet-exercise). Above all, as mentioned before, pharmacokinetic aspects related to use of nutraceutical molecules still need to be fully clarified, and before usage on a large scale, they should be analyzed in different clinical trials focused on lifestyle therapy.

In conclusion, T2DM and CVD are the principal global health threats of the future decades, and new dietetic regimes based on caloric restriction help to prevent the onset of these pathologies. However, many subjects fail to follow these dietary protocols, and identifying nutraceuticals capable of activating the same metabolic pathways of CR should be fundamental.

In this regard, berberine, resveratrol, quercetin, and L-carnitine have demonstrated CR properties. Nevertheless, the heterogeneity of data obtained using different doses of these dietary bioactive compounds represents the most crucial limit to propose specific recommendations. Moreover, current data show the importance of synergic action of diet and exercise and highlight the need to study the CR mimetics effects in relation to lifestyle therapeutic interventions (diet-exercise) to define nutritional recommendations for patients.

Author Contributions: P.S. and I.T. conceived the idea and drafted the manuscript; A.F. and L.L. edited the manuscript. All authors have read and agreed to the published version of the manuscript.

Funding: This work has been supported by Ministry of Health—Ricerca Corrente—IRCCS MultiMedica.

Conflicts of Interest: The authors declare no conflict of interest. 


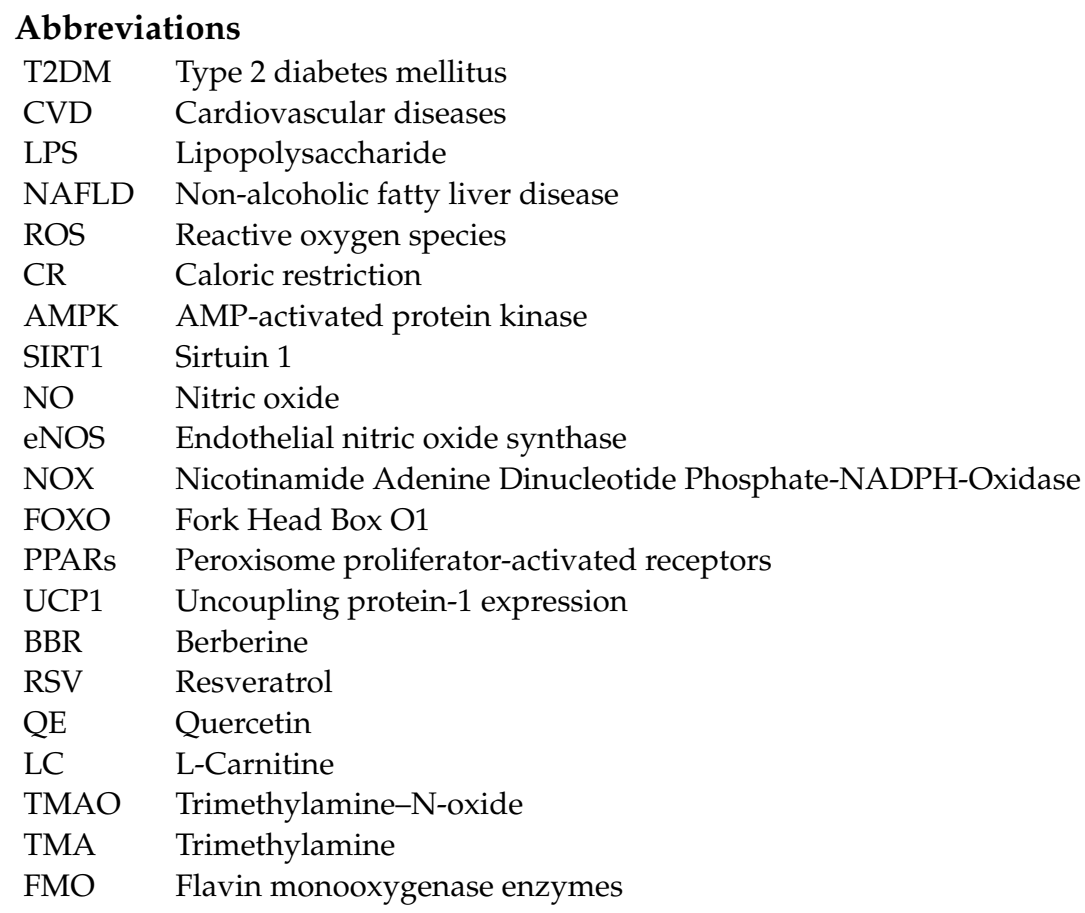

\section{References}

1. Weitzman, S. The link between diabetes and cardiovascular disease: The epidemiological perspective. Isr. Med. Assoc. J. 2016, 18, 709-711.

2. Viigimaa, M.; Sachinidis, A.; Toumpourleka, M.; Koutsampasopoulos, K.; Alliksoo, S.; Titma, T. Macrovascular Complications of Type 2 Diabetes Mellitus. Curr. Vasc. Pharmacol. 2020, 18, 110-116. [CrossRef]

3. Tan, Y.; Zhang, Z.; Zheng, C.; Wintergerst, K.A.; Keller, B.B.; Cai, L. Mechanisms of diabetic cardiomyopathy and potential therapeutic strategies: Preclinical and clinical evidence. Nat. Rev. Cardiol. 2020, 17, 585-607. [CrossRef] [PubMed]

4. Xia, J.; Yin, C. Glucose variability and coronary artery disease. Hear. Lung Circ. 2019, 28, 553-559. [CrossRef] [PubMed]

5. Shah, M.S.; Brownlee, M. Molecular and cellular mechanisms of cardiovascular disorders in diabetes. Circ. Res. 2016, 118, 1808-1829. [CrossRef] [PubMed]

6. Terruzzi, I.; Allibardi, S.; Bendinelli, P.; Maroni, P.; Piccoletti, R.; Vesco, F.; Samaja, M.; Luzi, L. Amino acid- and lipid-induced insulin resistance in rat heart: Molecular mechanisms. Mol. Cell. Endocrinol. 2002, 190, 135-145. [CrossRef]

7. Penna, C.; Andreadou, I.; Aragno, M.; Beauloye, C.; Bertrand, L.; Lazou, A.; Falcão-Pires, I.; Bell, R.; Zuurbier, C.J.; Pagliaro, P.; et al. Effect of hyperglycaemia and diabetes on acute myocardial ischaemia-reperfusion injury and cardioprotection by ischaemic conditioning protocols. Br. J. Pharmacol. 2020, 177, 5312-5335. [CrossRef]

8. Satthenapalli, V.R.; Lamberts, R.R.; Katare, R.G. Concise review: Challenges in regenerating the diabetic heart: A comprehensive review. Stem Cells. 2017, 35, 2009-2026. [CrossRef]

9. Poznyak, A.; Grechko, A.V.; Poggio, P.; Myasoedova, V.A.; Alfieri, V.; Orekhov, A.N. The diabetes mellitus-atherosclerosis connection: The role of lipid and glucose metabolism and chronic inflammation. Int. J. Mol. Sci. 2020, 21, 1835. [CrossRef]

10. Chait, A.; Hartigh, L.J.D. Adipose tissue distribution, inflammation and its metabolic consequences, including diabetes and cardiovascular disease. Front. Cardiovasc. Med. 2020, 7, 22. [CrossRef]

11. Patterson, E.; Ryan, P.M.; Cryan, J.F.; Dinan, T.G.; Ross, R.P.; Fitzgerald, G.F.; Stanton, C. Gut microbiota, obesity and diabetes. Postgrad. Med. J. 2016, 92, 286-300. [CrossRef] [PubMed]

12. Wen, L.; Duffy, A. Factors influencing the gut microbiota, inflammation, and type 2 diabetes. J. Nutr. 2017, 147, 1468S-1475S. [CrossRef] [PubMed]

13. Senesi, P.; Luzi, L.; Terruzzi, I. Adipokines, myokines, and cardiokines: The role of nutritional interventions. Int. J. Mol. Sci. 2020, 21, 8372. [CrossRef] [PubMed]

14. Guo, R.; Rogers, O.; Nair, S. Targeting Apelinergic System in Cardiometabolic Disease. Curr. Drug Targets 2017, 18, 1785-1791. [CrossRef] [PubMed]

15. Ahmad, A.; Yang, W.; Chen, G.; Shafiq, M.; Javed, S.; Zaidi, S.S.A.; Shahid, R.; Liu, C.; Bokhari, H. Analysis of gut microbiota of obese individuals with type 2 diabetes and healthy individuals. PLoS ONE 2019, 14, e0226372. [CrossRef] [PubMed]

16. Greenhill, C. Gut microbiota: Firmicutes and Bacteroidetes involved in insulin resistance by mediating levels of glucagon-like peptide 1. Nat. Rev. Endocrinol. 2015, 11, 254. [CrossRef]

17. Jiao, N.; Baker, S.S.; Nugent, C.A.; Tsompana, M.; Cai, L.; Wang, Y.; Buck, M.J.; Genco, R.J.; Baker, R.D.; Zhu, R.; et al. Gut microbiome may contribute to insulin resistance and systemic inflammation in obese rodents: A meta-analysis. Physiol. Genom. 2018, 50, 244-254. [CrossRef] 
18. Kim, K.A.; Jeong, J.J.; Yoo, S.Y.; Kim, D.H. Gut microbiota lipopolysaccharide accelerates inflamm-aging in mice. BMC Microbiol. 2016, 16, 1-9. [CrossRef]

19. Belizário, J.E.; Faintuch, J.; Garay-Malpartida, M. Gut microbiome dysbiosis and immunometabolism: New frontiers for treatment of metabolic diseases. Mediat. Inflamm. 2018, 2018, 1-12. [CrossRef]

20. Byrne, C.D.; Targher, G. NAFLD: A multisystem disease. J. Hepatol. 2015, 62, S47-S64. [CrossRef]

21. Safari, Z.; Gérard, P. The links between the gut microbiome and non-alcoholic fatty liver disease (NAFLD). Cell. Mol. Life Sci. 2019, 76, 1541-1558. [CrossRef]

22. Morrison, D.J.; Preston, T. Formation of short chain fatty acids by the gut microbiota and their impact on human metabolism. Gut Microbes 2016, 7, 189-200. [CrossRef]

23. Chu, H.; Duan, Y.; Yang, L.; Schnabl, B. Small metabolites, possible big changes: A microbiota-centered view of non-alcoholic fatty liver disease. Gut 2018, 68, 359-370. [CrossRef]

24. Adams, L.A.; Anstee, Q.M.; Tilg, H.; Targher, G. Non-alcoholic fatty liver disease and its relationship with cardiovascular disease and other extrahepatic diseases. Gut 2017, 66, 1138-1153. [CrossRef] [PubMed]

25. American Diabetes Association 4. Lifestyle management: Standards of medical care in diabetes-2018. Diabetes Care 2017, 41, S38-S50. [CrossRef]

26. Herrera, M.C.A.; Subhan, F.B.; Chan, C.B. Dietary patterns and cardiovascular disease risk in people with type 2 diabetes. Curr. Obes. Rep. 2017, 6, 405-413. [CrossRef] [PubMed]

27. Corella, D.; Ordovás, J.M. Papel de las ómicas en la nutrición de precisión: Fortalezas y debilidades [The role of omics in precision nutrition: Strengths and weaknesses]. Nutr. Hosp. 2018, 35, 10-18. [CrossRef] [PubMed]

28. Carrasco-Ramiro, F.; Peiró-Pastor, R.; Aguado, B. Human genomics projects and precision medicine. Gene Ther. 2017, $24,551-561$. [CrossRef]

29. Mathers, J.C. Nutrigenomics in the modern era. Proc. Nutr. Soc. 2016, 76, 265-275. [CrossRef]

30. Ren, X.; Li, X. Advances in research on diabetes by human nutriomics. Int. J. Mol. Sci. 2019, 20, 5375. [CrossRef]

31. Lean, M.E.J. Low-calorie diets in the management of type 2 diabetes mellitus. Nat. Rev. Endocrinol. 2019, 15, 251-252. [CrossRef]

32. Taylor, R. Calorie restriction for long-term remission of type 2 diabetes. Clin. Med. 2019, 19, 37-42. [CrossRef]

33. Yaribeygi, H.; Atkin, S.L.; Ramezani, M.; Sahebkar, A. A review of the molecular pathways mediating the improvement in diabetes mellitus following caloric restriction. J. Cell. Physiol. 2018, 234, 8436-8442. [CrossRef]

34. Rickman, A.D.; Williamson, D.A.; Martin, C.K.; Gilhooly, C.H.; Stein, R.I.; Bales, C.W.; Roberts, S.; Das, S.K. The CALERIE Study: Design and methods of an innovative 25\% caloric restriction intervention. Contemp. Clin. Trials 2011, 32, 874-881. [CrossRef]

35. Ma, L.; Wang, R.; Wang, H.; Zhang, Y.; Zhao, Z. Long-term caloric restriction activates the myocardial SIRT1/AMPK/PGC-1 $\alpha$ pathway in C57BL/6J male mice. Food Nutr. Res. 2020, 64. [CrossRef] [PubMed]

36. Weir, H.J.; Yao, P.; Huynh, F.K.; Escoubas, C.C.; Goncalves, R.L.; Burkewitz, K.; Laboy, R.; Hirschey, M.D.; Mair, W.B. Dietary restriction and AMPK increase lifespan via mitochondrial network and peroxisome remodeling. Cell Metab. 2017, 26, 884-896.e5. [CrossRef] [PubMed]

37. Velingkaar, N.; Mezhnina, V.; Poe, A.; Makwana, K.; Tulsian, R.; Kondratov, R.V. Reduced caloric intake and periodic fasting independently contribute to metabolic effects of caloric restriction. Aging Cell 2020, 19, e13138. [CrossRef] [PubMed]

38. Gensous, N.; Franceschi, C.; Santoro, A.; Milazzo, M.; Garagnani, P.; Bacalini, M.G. The impact of caloric restriction on the epigenetic signatures of aging. Int. J. Mol. Sci. 2019, 20, 2022. [CrossRef] [PubMed]

39. Pifferi, F.; Terrien, J.; Perret, M.; Epelbaum, J.; Blanc, S.; Picq, J.L.; Dhenain, M.; Aujard, F. Promoting healthspan and lifespan with caloric restriction in primates. Commun. Biol. 2019, 2, 107. [CrossRef] [PubMed]

40. Martin-Montalvo, A.; Mercken, E.M.; Mitchell, S.J.; Palacios, H.H.; Mote, P.L.; Scheibye-Knudsen, M.; Gomes, A.P.; Ward, T.M.; Minor, R.K.; Blouin, M.J.; et al. Metformin improves healthspan and lifespan in mice. Nat. Commun. 2013, 4, 2192. [CrossRef] [PubMed]

41. Senesi, P.; Montesano, A.; Luzi, L.; Codella, R.; Benedini, S.; Terruzzi, I. Metformin treatment prevents sedentariness related damages in mice. J. Diabetes Res. 2015, 2016, 1-11. [CrossRef]

42. Mehrabani, S.; Bagherniya, M.; Askari, G.; Read, M.I.; Sahebkar, A. The effect of fasting or calorie restriction on mitophagy induction: A literature review. J. Cachex-Sarcopenia Muscle 2020, 11, 1447-1458. [CrossRef] [PubMed]

43. Gutiérrez-Casado, E.; Khraiwesh, H.; López-Domínguez, J.A.; Montero-Guisado, J.; López-Lluch, G.; Navas, P.; de Cabo, R.; Ramsey, J.J.; González-Reyes, J.A.; Villalba, J.M. The impact of aging, calorie restriction and dietary fat on autophagy markers and mitochondrial ultrastructure and dynamics in mouse skeletal muscle. J. Gerontol. A Biol. Sci. Med. Sci. 2018, 74, 760-769. [CrossRef]

44. Tang, B.L. Sirt1 and the mitochondria. Mol. Cells. 2016, 39, 87-95. [CrossRef] [PubMed]

45. Lan, F.; Cacicedo, J.M.; Ruderman, N.; Ido, Y. SIRT1 modulation of the acetylation status, cytosolic localization, and activity of LKB1. Possible role in AMP-activated protein kinase activation. J. Biol. Chem. 2008, 283, 27628-27635. [CrossRef]

46. Rodríguez, C.; Muñoz, M.; Contreras, C.; Prieto, D. AMPK, metabolism, and vascular function. FEBS J. 2021, $288,3746-3771$. [CrossRef]

47. Finley, L.W.; Haigis, M.C. The coordination of nuclear and mitochondrial communication during aging and calorie restriction. Ageing Res. Rev. 2009, 8, 173-188. [CrossRef] [PubMed]

48. Shi, Y.; Vanhoutte, P.M. Macro- and microvascular endothelial dysfunction in diabetes. J. Diabetes 2017, 9, 434-449. [CrossRef] 
49. Incalza, M.A.; D’Oria, R.; Natalicchio, A.; Perrini, S.; Laviola, L.; Giorgino, F.; Incalza, M.A.; D'Oria, R.; Natalicchio, A.; Perrini, S.; et al. Oxidative stress and reactive oxygen species in endothelial dysfunction associated with cardiovascular and metabolic diseases. Vasc. Pharmacol. 2018, 100, 1-19. [CrossRef]

50. Grandl, G.; Wolfrum, C. Hemostasis, endothelial stress, inflammation, and the metabolic syndrome. Semin. Immunopathol. 2017, 40, 215-224. [CrossRef]

51. Ojagbemi, A.; Okekunle, A.P.; Olowoyo, P.; Akpa, O.M.; Akinyemi, R.; Ovbiagele, B.; Owolabi, M. Dietary intakes of green leafy vegetables and incidence of cardiovascular diseases. Cardiovasc. J. Afr. 2021, 32, 1-9. [CrossRef]

52. Zhao, Y.; Vanhoutte, P.M.; Leung, S.W. Vascular nitric oxide: Beyond eNOS. J. Pharmacol. Sci. 2015, 129, 83-94. [CrossRef]

53. Vermot, A.; Petit-Härtlein, I.; Smith, S.M.E.; Fieschi, F. NADPH Oxidases (NOX): An overview from discovery, molecular mechanisms to physiology and pathology. Antioxidants 2021, 10, 890. [CrossRef] [PubMed]

54. Sasaki, S.; Higashi, Y.; Nakagawa, K.; Kimura, M.; Noma, K.; Sasaki, S.; Hara, K.; Matsuura, H.; Goto, C.; Oshima, T.; et al. A low-calorie diet improves endothelium-dependent vasodilation in obese patients with essential hypertension. Am. J. Hypertens. 2002, 15, 302-309. [CrossRef]

55. Dolinsky, V.W.; Morton, J.S.; Oka, T.; Robillard-Frayne, I.; Bagdan, M.; Lopaschuk, G.D.; Des Rosiers, C.; Walsh, K.; Davidge, S.T.; Dyck, J.R. Calorie restriction prevents hypertension and cardiac hypertrophy in the spontaneously hypertensive rat. Hypertension 2010, 56, 412-421. [CrossRef] [PubMed]

56. Kröller-Schön, S.; Daiber, A.; Schulz, E. Modulation of vascular function by AMPK: Assessment of NO bioavailability and surrogates of oxidative stress. Methods Mol. Biol. 2018, 1732, 495-506. [CrossRef] [PubMed]

57. García-Prieto, C.F.; Pulido-Olmo, H.; Ruiz-Hurtado, G.; Gil-Ortega, M.; Aranguez, I.; Rubio, M.A.; Ruiz-Gayo, M.; Somoza, B.; Fernández-Alfonso, M.S. Mild caloric restriction reduces blood pressure and activates endothelial AMPK-PI3K-Akt-eNOS pathway in obese Zucker rats. Vasc. Pharmacol. 2015, 65-66, 3-12. [CrossRef] [PubMed]

58. García-Prieto, C.F.; Gil-Ortega, M.; Plaza, A.; Manzano-Lista, F.J.; González-Blázquez, R.; Alcalá, M.; Rodríguez-Rodríguez, P.; Viana, M.; Aránguez, I.; Gollasch, M.; et al. Caloric restriction induces H2O2 formation as a trigger of AMPK-eNOS-NO pathway in obese rats: Role for CAMKII. Free. Radic. Biol. Med. 2019, 139, 35-45. [CrossRef] [PubMed]

59. Rodríguez, C.; Contreras, C.; Sáenz-Medina, J.; Muñoz, M.; Corbacho, C.; Carballido, J.; García-Sacristán, A.; Hernandez, M.; López, M.; Rivera, L.; et al. Activation of the AMP-related kinase (AMPK) induces renal vasodilatation and downregulates Nox-derived reactive oxygen species (ROS) generation. Redox Biol. 2020, 34, 101575. [CrossRef]

60. Hasan, R.; Lasker, S.; Hasan, A.; Zerin, F.; Zamila, M.; Chowdhury, F.I.; Nayan, S.I.; Rahman, M.M.; Khan, F.; Subhan, N.; et al. Canagliflozin attenuates isoprenaline-induced cardiac oxidative stress by stimulating multiple antioxidant and anti-inflammatory signaling pathways. Sci. Rep. 2020, 10, 1-19. [CrossRef]

61. Mattagajasingh, I.; Kim, C.S.; Naqvi, A.; Yamamori, T.; Hoffman, T.A.; Jung, S.B.; DeRicco, J.; Kasuno, K.; Irani, K. SIRT1 promotes endothelium-dependent vascular relaxation by activating endothelial nitric oxide synthase. Proc. Natl. Acad. Sci. USA 2007, 104, 14855-14860. [CrossRef]

62. Lempiäinen, J.; Finckenberg, P.; Mervaala, E.E.; Sankari, S.; Levijoki, J.; Mervaala, E.M. Caloric restriction ameliorates kidney ischaemia/reperfusion injury through PGC-1 $\alpha$-eNOS pathway and enhanced autophagy. Acta Physiol. 2013, 208, 410-421. [CrossRef]

63. Luo, X.; Hu, Y.; He, S.; Ye, Q.; Lv, Z.; Liu, J.; Chen, X. Dulaglutide inhibits high glucose- induced endothelial dysfunction and NLRP3 inflammasome activation. Arch. Biochem. Biophys. 2019, 671, 203-209. [CrossRef]

64. Villena, J.A. New insights into PGC-1 coactivators: Redefining their role in the regulation of mitochondrial function and beyond. FEBS J. 2015, 282, 647-672. [CrossRef] [PubMed]

65. Yap, K.H.; Yee, G.S.; Candasamy, M.; Tan, S.C.; Md, S.; Majeed, A.B.A.; Bhattamisra, S.K. Catalpol ameliorates insulin sensitivity and mitochondrial respiration in skeletal muscle of Type-2 diabetic mice through insulin signaling pathway and AMPK/SIRT1/PGC-1 $\alpha$ /PPAR- $\gamma$ activation. Biomolecules 2020, 10, 1360. [CrossRef] [PubMed]

66. Waldman, M.; Nudelman, V.; Shainberg, A.; Zemel, R.; Kornwoski, R.; Aravot, D.; Peterson, S.J.; Arad, M.; Hochhauser, E. The role of heme oxygenase 1 in the protective effect of caloric restriction against diabetic cardiomyopathy. Int. J. Mol. Sci. 2019, 20, 2427. [CrossRef]

67. Singh, V.; Ubaid, S. Role of silent information regulator 1 (SIRT1) in regulating oxidative stress and inflammation. Inflamm. 2020, 43, 1589-1598. [CrossRef] [PubMed]

68. Kobayashi, Y.; Furukawa-Hibi, Y.; Chen, C.; Horio, Y.; Isobe, K.; Ikeda, K.; Motoyama, N. SIRT1 is critical regulator of FOXOmediated transcription in response to oxidative stress. Int. J. Mol. Med. 2005, 16, 237-243. [CrossRef]

69. Greer, E.L.; Banko, M.R.; Brunet, A. AMP-activated protein kinase and FoxO transcription factors in dietary restriction-induced longevity. Ann. N. Y. Acad. Sci. 2009, 1170, 688-692. [CrossRef] [PubMed]

70. Kauppinen, A.; Suuronen, T.; Ojala, J.; Kaarniranta, K.; Salminen, A. Antagonistic crosstalk between NF-kB and SIRT1 in the regulation of inflammation and metabolic disorders. Cell. Signal. 2013, 25, 1939-1948. [CrossRef]

71. Jordan, S.; Tung, N.; Casanova-Acebes, M.; Chang, C.; Cantoni, C.; Zhang, D.; Wirtz, T.H.; Naik, S.; Rose, S.A.; Brocker, C.N.; et al. Dietary intake regulates the circulating inflammatory monocyte pool. Cell 2019, 178, 1102-1114.e17. [CrossRef]

72. Cohen, K.; Waldman, M.; Abraham, N.G.; Laniado-Schwartzman, M.; Gurfield, D.; Aravot, D.; Arad, M.; Hochhauser, E. Caloric restriction ameliorates cardiomyopathy in animal model of diabetes. Exp. Cell Res. 2017, 350, 147-153. [CrossRef] 
73. Corrales, P.; Vidal-Puig, A.; Medina-Gómez, G. PPARs and metabolic disorders associated with challenged adipose tissue plasticity. Int. J. Mol. Sci. 2018, 19, 2124. [CrossRef]

74. 74. Bargut, T.C.L.; Souza-Mello, V.; Aguila, M.B.; Mandarim-de-Lacerda, C.A. Browning of white adipose tissue: Lessons from experimental models. Horm. Mol. Biol. Clin. Investig. 2017, 31. [CrossRef]

75. Aquilano, K.; Sciarretta, F.; Turchi, R.; Li, B.-H.; Rosina, M.; Ceci, V.; Guidobaldi, G.; Arena, S.; D’Ambrosio, C.; Audano, M.; et al Low-protein/high-carbohydrate diet induces AMPK-dependent canonical and non-canonical thermogenesis in subcutaneous adipose tissue. Redox Biol. 2020, 36, 101633. [CrossRef]

76. Qiang, L.; Wang, L.; Kon, N.; Zhao, W.; Lee, S.; Zhang, Y.; Rosenbaum, M.; Zhao, Y.; Gu, W.; Farmer, S.; et al. Brown remodeling of white adipose tissue by SirT1-dependent deacetylation of Ppar $\gamma$. Cell 2012, 150, 620-632. [CrossRef]

77. Boström, P.; Wu, J.; Jedrychowski, M.P.; Korde, A.; Ye, L.; Lo, J.C.; Rasbach, K.A.; Boström, E.A.; Choi, J.H.; Long, J.Z.; et al. A PGC1- $\alpha$-dependent myokine that drives brown-fat-like development of white fat and thermogenesis. Nat. Cell Biol. 2012, 481, 463-468. [CrossRef] [PubMed]

78. Yang, X.; Liu, Q.; Li, Y.; Tang, Q.; Wu, T.; Chen, L.; Pu, S.; Zhao, Y.; Zhang, G.; Huang, C.; et al. The diabetes medication canagliflozin promotes mitochondrial remodelling of adipocyte via the AMPK-Sirt1-Pgc-1 $\alpha$ signalling pathway. Adipocyte 2020, 9 , 484-494. [CrossRef] [PubMed]

79. Jamwal, S.; Blackburn, J.K.; Elsworth, J.D. PPAR $\gamma /$ PGC1 $\alpha$ signaling as a potential therapeutic target for mitochondrial biogenesis in neurodegenerative disorders. Pharmacol. Ther. 2021, 219, 107705. [CrossRef] [PubMed]

80. Fujii, N.; Uta, S.; Kobayashi, M.; Sato, T.; Okita, N.; Higami, Y. Impact of aging and caloric restriction on fibroblast growth factor 21 signaling in rat white adipose tissue. Exp. Gerontol. 2019, 118, 55-64. [CrossRef] [PubMed]

81. Yang, Y.B.; Wu, X.L.; Ke, B.; Huang, Y.J.; Chen, S.Q.; Su, Y.Q.; Qin, J. Effects of caloric restriction on peroxisome proliferatoractivated receptors and positive transcription elongation factor b expression in obese rats. Eur. Rev. Med. Pharmacol. Sci. 2017, 21, 4369-4378.

82. Medina-Gomez, G.; Gray, S.; Vidal-Puig, A. Adipogenesis and lipotoxicity: Role of peroxisome proliferator-activated receptor gamma (PPARgamma) and PPARgammacoactivator-1 (PGC1). Public Heal. Nutr. 2007, 10, 1132-1137. [CrossRef]

83. Liu, F.; Fang, S.; Liu, X.; Li, J.; Wang, X.; Cui, J.; Chen, T.; Li, Z.; Yang, F.; Tian, J.; et al. Omentin-1 protects against high glucose-induced endothelial dysfunction via the AMPK/PPAR s signaling pathway. Biochem Pharmacol. 2020, 174, 113830. [CrossRef]

84. Okazaki, M.; Iwasaki, Y.; Nishiyama, M.; Taguchi, T.; Tsugita, M.; Nakayama, S.; Kambayashi, M.; Hashimoto, K.; Terada, Y. PPARbeta/delta regulates the human SIRT1 gene transcription via Sp1. Endocr. J. 2010, 57, 403-413. [CrossRef] [PubMed]

85. Liu, Y.; Colby, J.K.; Zuo, X.; Jaoude, J.; Wei, D.; Shureiqi, I. The role of PPAR- $\delta$ in metabolism, inflammation, and cancer: Many characters of a critical transcription factor. Int. J. Mol. Sci. 2018, 19, 3339. [CrossRef] [PubMed]

86. Gan, Z.; Burkart-Hartman, E.M.; Han, D.H.; Finck, B.; Leone, T.C.; Smith, E.Y.; Ayala, J.E.; Holloszy, J.; Kelly, D.P. The nuclear receptor PPAR $\beta / \delta$ programs muscle glucose metabolism in cooperation with AMPK and MEF2. Genes Dev. 2011, 25, 2619-2630. [CrossRef] [PubMed]

87. Paoli, A.; Tinsley, G.; Bianco, A.; Moro, T. The influence of meal frequency and timing on health in humans: The role of fasting. Nutrients 2019, 11, 719. [CrossRef]

88. Zheng, X.; Wang, S.; Jia, W. Calorie restriction and its impact on gut microbial composition and global metabolism. Front. Med. 2018, 12, 634-644. [CrossRef]

89. Banini, B.A.; Sanyal, A.J. Current and future pharmacologic treatment of nonalcoholic steatohepatitis. Curr. Opin. Gastroenterol. 2017, 33, 134-141. [CrossRef]

90. Wang, S.; Huang, M.; You, X.; Zhao, J.; Chen, L.; Wang, L.; Luo, Y.; Chen, Y. Gut microbiota mediates the anti-obesity effect of calorie restriction in mice. Sci. Rep. 2018, 8, 1-14. [CrossRef]

91. Moreno-Navarrete, J.M.; Fernandez-Real, J.M. The gut microbiota modulates both browning of white adipose tissue and the activity of brown adipose tissue. Rev. Endocr. Metab. Disord. 2019, 20, 387-397. [CrossRef] [PubMed]

92. Corrales, P.; Vivas-García, Y.; Izquierdo-Lahuerta, A.; Horrillo, D.; Seoane-Collazo, P.; Velasco, I.; Torres, L.; Lopez, Y.; Martínez, C.; López, M.; et al. Long-term caloric restriction ameliorates deleterious effects of aging on white and brown adipose tissue plasticity. Aging Cell 2019, 18, e12948. [CrossRef]

93. Harper, C.; Maher, J.; Grunseit, A.; Seimon, R.V.; Sainsbury, A. Experiences of using very low energy diets for weight loss by people with overweight or obesity: A review of qualitative research. Obes. Rev. 2018, 19, 1412-1423. [CrossRef] [PubMed]

94. Martens, C.R.; Seals, D.R. Practical alternatives to chronic caloric restriction for optimizing vascular function with ageing. J. Physiol. 2016, 594, 7177-7195. [CrossRef]

95. Mariño, G.; Pietrocola, F.; Madeo, F.; Kroemer, G. Caloric restriction mimetics: Natural/physiological pharmacological autophagy inducers. Autophagy 2014, 10, 1879-1882. [CrossRef]

96. Madeo, F.; Pietrocola, F.; Eisenberg, T.; Kroemer, G. Caloric restriction mimetics: Towards a molecular definition. Nat. Rev. Drug Discov. 2014, 13, 727-740. [CrossRef]

97. Pietrocola, F.; Castoldi, F.; Maiuri, M.C.; Kroemer, G. Aspirin-another caloric-restriction mimetic. Autophagy 2018, 14, 1162-1163. [CrossRef]

98. Cicero, A.F.; Baggioni, A. Berberine and its role in chronic disease. Adv. Exp. Med. Biol. 2016, 928, 27-45. [CrossRef] [PubMed] 
99. Hu, X.; Zhang, Y.; Xue, Y.; Zhang, Z.; Wang, J. Berberine is a potential therapeutic agent for metabolic syndrome via brown adipose tissue activation and metabolism regulation. Am. J. Transl. Res. 2018, 10, 3322-3329. [PubMed]

100. Tabeshpour, J.; Imenshahidi, M.; Hosseinzadeh, H. A review of the effects of Berberis vulgaris and its major component, berberine, in metabolic syndrome. Iran. J. Basic. Med. Sci. 2017, 20, 557-568. [CrossRef]

101. Chang, W.; Chen, L.; Hatch, G.M. Berberine as a therapy for type 2 diabetes and its complications: From mechanism of action to clinical studies. Biochem. Cell Biol. 2015, 93, 479-486. [CrossRef] [PubMed]

102. Ma, X.; Chen, Z.; Wang, L.; Wang, G.; Wang, Z.; Dong, X.; Wen, B.; Zhang, Z. The pathogenesis of diabetes mellitus by oxidative stress and inflammation: Its inhibition by berberine. Front. Pharmacol. 2018, 9, 782. [CrossRef]

103. Yao, S.; Yuan, Y.; Zhang, H.; Meng, X.; Jin, L.; Yang, J.; Wang, W.; Ning, G.; Zhang, Y.; Zhang, Z. Berberine attenuates the abnormal ectopic lipid deposition in skeletal muscle. Free. Radic. Biol. Med. 2020, 159, 66-75. [CrossRef]

104. Ren, G.; Guo, J.H.; Qian, Y.Z.; Kong, W.J.; Jiang, J.D. Berberine improves glucose and lipid metabolism in HepG2 cells through AMPK $\alpha 1$ activation. Front. Pharmacol. 2020, 11. [CrossRef]

105. Wu, Y.S.; Li, Z.M.; Chen, Y.T.; Dai, S.J.; Zhou, X.J.; Yang, Y.X.; Lou, J.S.; Ji, L.T.; Bao, Y.T.; Xuan, L.; et al. Berberine improves inflammatory responses of diabetes mellitus in zucker diabetic fatty rats and insulin-resistant HepG2 cells through the PPM1B pathway. J. Immunol. Res. 2020, 2020, 1-32. [CrossRef]

106. Wang, L.; Ye, X.; Hua, Y.; Song, Y. Berberine alleviates adipose tissue fibrosis by inducing AMP-activated kinase signaling in high-fat diet-induced obese mice. Biomed. Pharmacother. 2018, 105, 121-129. [CrossRef]

107. Shan, Y.; Zhang, S.; Gao, B.; Liang, S.; Zhang, H.; Yu, X.; Zhao, J.; Ye, L.; Yang, Q.; Shang, W. Adipose tissue SIRT1 regulates insulin sensitizing and anti-inflammatory effects of berberine. Front. Pharmacol. 2020, 11. [CrossRef] [PubMed]

108. Wu, L.; Xia, M.; Duan, Y.; Zhang, L.; Jiang, H.; Hu, X.; Yan, H.; Zhang, Y.; Gu, Y.; Shi, H.; et al. Berberine promotes the recruitment and activation of brown adipose tissue in mice and humans. Cell Death Dis. 2019, 10, 468. [CrossRef] [PubMed]

109. Hang, W.; He, B.; Chen, J.; Xia, L.; Wen, B.; Liang, T.; Wang, X.; Zhang, Q.; Wu, Y.; Chen, Q.; et al. Berberine ameliorates high glucose-induced cardiomyocyte injury via AMPK signaling activation to stimulate mitochondrial biogenesis and restore autophagic flux. Front. Pharmacol. 2018, 9. [CrossRef]

110. Chang, W.; Li, K.; Guan, F.; Yao, F.; Yu, Y.; Zhang, M.; Hatch, G.M.; Chen, L. Berberine pretreatment confers cardioprotection against ischemia-reperfusion injury in a rat model of type 2 diabetes. J. Cardiovasc. Pharmacol. Ther. 2016, 21, 486-494. [CrossRef]

111. Wang, Y.; Huang, Y.; Lam, K.S.; Li, Y.; Wong, W.T.; Ye, H.; Lau, C.-W.; Vanhoutte, P.M.; Xu, A. Berberine prevents hyperglycemiainduced endothelial injury and enhances vasodilatation via adenosine monophosphate-activated protein kinase and endothelial nitric oxide synthase. Cardiovasc. Res. 2009, 82, 484-492. [CrossRef] [PubMed]

112. Liu, D.; Zhang, Y.; Liu, Y.; Hou, L.; Li, S.; Tian, H.; Zhao, T. Berberine modulates gut microbiota and reduces insulin resistance via the TLR4 signaling pathway. Exp. Clin. Endocrinol. Diabetes 2018, 126, 513-520. [CrossRef] [PubMed]

113. Wang, Y.; Shou, J.-W.; Li, X.-Y.; Zhao, Z.-X.; Fu, J.; He, C.-Y.; Feng, R.; Ma, C.; Wen, B.-Y.; Guo, F.; et al. Berberine-induced bioactive metabolites of the gut microbiota improve energy metabolism. Metabolism 2017, 70, 72-84. [CrossRef] [PubMed]

114. Tian, Y.; Cai, J.; Gui, W.; Nichols, R.; Koo, I.; Zhang, J.; Anitha, M.; Patterson, A.D. Berberine directly affects the gut microbiota to promote intestinal farnesoid $X$ receptor activation. Drug Metab. Dispos. 2018, 47, 86-93. [CrossRef] [PubMed]

115. Shi, Y.; Hu, J.; Geng, J.; Hu, T.; Wang, B.; Yan, W.; Jiang, Y.; Li, J.; Liu, S. Berberine treatment reduces atherosclerosis by mediating gut microbiota in apoE-/- mice. Biomed. Pharmacother. 2018, 107, 1556-1563. [CrossRef]

116. Xiong, P.; Niu, L.; Talaei, S.; Kord-Varkaneh, H.; Clark, C.; Găman, M.-A.; Rahmani, J.; Dorosti, M.; Mousavi, S.M.; Zarezadeh, M.; et al. The effect of berberine supplementation on obesity indices: A dose- response meta-analysis and systematic review of randomized controlled trials. Complement. Ther. Clin. Pr. 2020, 39, 101113. [CrossRef] [PubMed]

117. Beba, M.; Djafarian, K.; Shab-Bidar, S. Effect of Berberine on C-reactive protein: A systematic review and meta-analysis of randomized controlled trials. Complement. Ther. Med. 2019, 46, 81-86. [CrossRef]

118. Asbaghi, O.; Ghanbari, N.; Shekari, M.; Reiner, Ž.; Amirani, E.; Hallajzadeh, J.; Mirsafaei, L.; Asemi, Z. The effect of berberine supplementation on obesity parameters, inflammation and liver function enzymes: A systematic review and meta-analysis of randomized controlled trials. Clin. Nutr. ESPEN 2020, 38, 43-49. [CrossRef]

119. Nawaz, W.; Zhou, Z.; Deng, S.; Ma, X.; Ma, X.; Li, C.; Shu, X. Therapeutic versatility of resveratrol derivatives. Nutrients 2017, 9 , 1188. [CrossRef]

120. Castaldo, L.; Narváez, A.; Izzo, L.; Graziani, G.; Gaspari, A.; Di Minno, G.; Ritieni, A. Red wine consumption and cardiovascular health. Molecules 2019, 24, 3626. [CrossRef]

121. Breuss, J.M.; Atanasov, A.G.; Uhrin, P. Resveratrol and its effects on the vascular system. Int. J. Mol. Sci. 2019, 20, 1523. [CrossRef]

122. Elgebaly, A.; Radwan, I.; AboElnas, M.; Ibrahim, H.H.; Eltoomy, M.F.M.; Atta, A.A.; Mesalam, H.A.; Sayed, A.A.; Othman, A.A. Resveratrol supplementation in patients with non-alcoholic fatty liver disease: Systematic review and meta-analysis. $J$. Gastrointest. Liver Dis. 2017, 26, 59-67. [CrossRef]

123. Jeyaraman, M.M.; Al-Yousif, N.S.H.; Mann, A.S.; Dolinsky, V.W.; Rabbani, R.; Zarychanski, R.; Abou-Setta, A.M. Resveratrol for adults with type 2 diabetes mellitus. Cochrane Database Syst. Rev. 2020, 1, CD011919. [CrossRef]

124. Pan, M.-H.; Wu, J.-C.; Ho, C.-T.; Lai, C.-S. Antiobesity molecular mechanisms of action: Resveratrol and pterostilbene. BioFactors 2018, 44, 50-60. [CrossRef] [PubMed]

125. Chaplin, A.; Carpéné, C.; Mercader, J. Resveratrol, metabolic syndrome, and gut microbiota. Nutrients 2018, 10, 1651. [CrossRef] [PubMed] 
126. Akar, F.; Uludağ, O.; Aydın, A.; Aytekin, Y.A.; Elbeg, S.; Tuzcu, M.; Sahin, K. High-fructose corn syrup causes vascular dysfunction associated with metabolic disturbance in rats: Protective effect of resveratrol. Food Chem. Toxicol. 2012, 50, 2135-2141. [CrossRef]

127. Cheng, P.-W.; Lee, H.-C.; Lu, P.-J.; Chen, H.-H.; Lai, C.-C.; Sun, G.-C.; Yeh, T.-C.; Hsiao, M.; Lin, Y.-T.; Liu, C.-P.; et al. Resveratrol inhibition of Rac1-derived reactive oxygen species by AMPK decreases blood pressure in a fructose-induced rat model of hypertension. Sci. Rep. 2016, 6, 25342. [CrossRef] [PubMed]

128. Bhatt, S.R.; Lokhandwala, M.F.; Banday, A.A. Resveratrol prevents endothelial nitric oxide synthase uncoupling and attenuates development of hypertension in spontaneously hypertensive rats. Eur. J. Pharmacol. 2011, 667, 258-264. [CrossRef] [PubMed]

129. Ding, S.; Jiang, J.; Zhang, G.; Bu, Y.; Zhang, G.; Zhao, X. Resveratrol and caloric restriction prevent hepatic steatosis by regulating SIRT1-autophagy pathway and alleviating endoplasmic reticulum stress in high-fat diet-fed rats. PLoS ONE 2017, 12, e0183541. [CrossRef] [PubMed]

130. Shang, J.; Chen, L.-L.; Xiao, F.-X.; Sun, H.; Ding, H.-C.; Xiao, H. Resveratrol improves non-alcoholic fatty liver disease by activating AMP-activated protein kinase. Acta Pharmacol. Sin. 2008, 29, 698-706. [CrossRef] [PubMed]

131. Huang, Y.; Lang, H.; Chen, K.; Zhang, Y.; Gao, Y.; Ran, L.; Yi, L.; Mi, M.; Zhang, Q. Resveratrol protects against nonalcoholic fatty liver disease by improving lipid metabolism and redox homeostasis via the PPAR $\alpha$ pathway. Appl. Physiol. Nutr. Metab. 2020, 45, 227-239. [CrossRef] [PubMed]

132. Teng, W.; Zhao, L.; Yang, S.; Zhang, C.; Liu, M.; Luo, J.; Jin, J.; Zhang, M.; Bao, C.; Li, D.; et al. The hepatic-targeted, resveratrol loaded nanoparticles for relief of high fat diet-induced nonalcoholic fatty liver disease. J. Control. Release 2019, 307, 139-149. [CrossRef] [PubMed]

133. Chen, S.; Zhao, Z.; Ke, L.; Li, Z.; Li, W.; Zhang, Z.; Zhou, Y.; Feng, X.; Zhu, W. Resveratrol improves glucose uptake in insulin-resistant adipocytes via Sirt1. J. Nutr. Biochem. 2018, 55, 209-218. [CrossRef] [PubMed]

134. Vlavcheski, F.; Hartogh, D.J.D.; Giacca, A.; Tsiani, E. Amelioration of high-insulin-induced skeletal muscle cell insulin resistance by resveratrol is linked to activation of AMPK and restoration of GLUT4 translocation. Nutrients 2020, 12, 914. [CrossRef]

135. Shu, L.; Zhao, H.; Huang, W.; Hou, G.; Song, G.; Ma, H. Resveratrol upregulates mmu-miR-363-3p via the PI3K-Akt pathway to improve insulin resistance induced by a high-fat diet in mice. Diabetes, Metab. Syndr. Obesity: Targets Ther. 2020; ume 13, 391-403. [CrossRef]

136. Andrade, J.M.O.; Barcala-Jorge, A.S.; Batista-Jorge, G.C.; Paraíso, A.F.; Freitas, K.M.; Lelis, D.F.; Guimarães, A.L.S.; de Paula, A.M.B.; Santos, S.H.S. Effect of resveratrol on expression of genes involved thermogenesis in mice and humans. Biomed. Pharmacother. 2019, 112, 108634. [CrossRef] [PubMed]

137. Wang, S.; Liang, X.; Yang, Q.; Fu, X.; Rogers, C.J.; Zhu, M.; Rodgers, B.D.; Jiang, Q.; Dodson, M.V.; Du, M. Resveratrol induces brown-like adipocyte formation in white fat through activation of AMP-activated protein kinase (AMPK) $\alpha 1$. Int. J. Obes. 2015, 39, 967-976. [CrossRef]

138. Hui, S.; Liu, Y.; Huang, L.; Zheng, L.; Zhou, M.; Lang, H.; Wang, X.; Yi, L.; Mi, M. Resveratrol enhances brown adipose tissue activity and white adipose tissue browning in part by regulating bile acid metabolism via gut microbiota remodeling. Int. J. Obes. 2020, 44, 1678-1690. [CrossRef]

139. Liao, W.; Yin, X.; Li, Q.; Zhang, H.; Liu, Z.; Zheng, X.; Zheng, L.; Feng, X. Resveratrol-induced white adipose tissue browning in obese mice by remodeling fecal microbiota. Molecules 2018, 23, 3356. [CrossRef]

140. Campbell, C.L.; Yu, R.; Li, F.; Zhou, Q.; Chen, D.; Qi, C.; Yin, Y.; Sun, J. Modulation of fat metabolism and gut microbiota by resveratrol on high-fat diet-induced obese mice. Diabetes Metab. Syndr. Obes. 2019, 12, 97-107. [CrossRef]

141. Chen, M.-L.; Yi, L.; Zhang, Y.; Zhou, X.; Ran, L.; Yang, J.; Zhu, J.-D.; Zhang, Q.-Y.; Mi, M.-T. Resveratrol attenuates Trimethylamine$\mathrm{N}$-Oxide (TMAO)-induced atherosclerosis by regulating TMAO synthesis and bile acid metabolism via remodeling of the gut microbiota. mBio 2016, 7, e02210-15. [CrossRef]

142. Parsamanesh, N.; Asghari, A.; Sardari, S.; Tasbandi, A.; Jamialahmadi, T.; Xu, S.; Sahebkar, A. Resveratrol and endothelial function: A literature review. Pharmacol. Res. 2021, 170, 105725. [CrossRef]

143. Jakubczyk, K.; Skonieczna-Żydecka, K.; Kałduńska, J.; Stachowska, E.; Gutowska, I.; Janda, K. Effects of resveratrol supplementation in patients with non-alcoholic fatty liver disease-A meta-analysis. Nutrients 2020, 12, 2435. [CrossRef]

144. Pollack, R.M.; Barzilai, N.; Anghel, V.; Kulkarni, A.; Golden, A.; Broin, P.; Sinclair, D.; Bonkowski, M.; Coleville, A.J.; Powell, D.; et al. Resveratrol improves vascular function and mitochondrial number but not glucose metabolism in older adults. J. Gerontol. A Biol. Sci. Med. Sci. 2017, 72, 1703-1709. [CrossRef] [PubMed]

145. Kang, W.; Hong, H.J.; Guan, J.; Kim, D.G.; Yang, E.-J.; Koh, G.; Park, D.; Han, C.H.; Lee, Y.-J.; Lee, D.-H.; et al. Resveratrol improves insulin signaling in a tissue-specific manner under insulin-resistant conditions only: In vitro and in vivo experiments in rodents. Metabolism 2012, 61, 424-433. [CrossRef] [PubMed]

146. Montesano, A.; Luzi, L.; Senesi, P.; Mazzocchi, N.; Terruzzi, I. Resveratrol promotes myogenesis and hypertrophy in murine myoblasts. J. Transl. Med. 2013, 11, 310. [CrossRef]

147. Wang, P.; Sang, S. Metabolism and pharmacokinetics of resveratrol and pterostilbene. Biofactors. 2018, 44, 16-25. [CrossRef] [PubMed]

148. Batiha, G.E.-S.; Beshbishy, A.M.; Ikram, M.; Mulla, Z.S.; El-Hack, M.E.A.; Taha, A.E.; Algammal, A.M.; Elewa, Y.H.A. The pharmacological activity, biochemical properties, and pharmacokinetics of the major natural polyphenolic flavonoid: Quercetin. Foods 2020, 9, 374. [CrossRef] [PubMed] 
149. Ferenczyova, K.; Kalocayova, B.; Bartekova, M. Potential implications of quercetin and its derivatives in cardioprotection. Int. J. Mol. Sci. 2020, 21, 1585. [CrossRef]

150. Chen, S.; Jiang, H.; Wu, X.; Fang, J. Therapeutic effects of quercetin on inflammation, obesity, and type 2 diabetes. Mediat. Inflamm. 2016, 2016, 1-5. [CrossRef]

151. Murota, K.; Nakamura, Y.; Uehara, M. Flavonoid metabolism: The interaction of metabolites and gut microbiota. Biosci. Biotechnol. Biochem. 2018, 82, 600-610. [CrossRef]

152. Calabró, V.; Litterio, M.C.; Fraga, C.G.; Galleano, M.; Piotrkowski, B. Effects of quercetin on heart nitric oxide metabolism in 1-NAME treated rats. Arch. Biochem. Biophys. 2018, 647, 47-53. [CrossRef] [PubMed]

153. Kim, S.G.; Kim, J.-R.; Choi, H.C.; Kim, S.G.; Kim, J.-R.; Choi, H.C. Quercetin-induced AMP-activated protein kinase activation attenuates vasoconstriction through LKB1-AMPK signaling pathway. J. Med. Food 2018, 21, 146-153. [CrossRef] [PubMed]

154. Yan, L.; Zhang, J.D.; Wang, B.; Lv, Y.J.; Jiang, H.; Liu, G.L.; Qiao, Y.; Ren, M.; Guo, X.F. Quercetin inhibits left ventricular hypertrophy in spontaneously hypertensive rats and inhibits angiotensin II-induced H9C2 cells hypertrophy by enhancing PPAR- $\gamma$ expression and suppressing AP-1 activity. PLoS ONE 2013, 8, e72548. [CrossRef] [PubMed]

155. Ulasova, E.; Perez, J.; Hill, B.; Bradley, W.E.; Garber, D.W.; Landar, A.; Barnes, S.; Prasain, J.; Parks, D.A.; Dell’Italia, L.J.; et al. Quercetin prevents left ventricular hypertrophy in the Apo E knockout mouse. Redox Biol. 2013, 1, 381-386. [CrossRef] [PubMed]

156. Guo, G.; Gong, L.; Sun, L.; Xu, H. Quercetin supports cell viability and inhibits apoptosis in cardiocytes by down-regulating miR-199a. Artif. Cells, Nanomedicine, Biotechnol. 2019, 47, 2909-2916. [CrossRef] [PubMed]

157. Roslan, J.; Giribabu, N.; Karim, K.; Salleh, N. Quercetin ameliorates oxidative stress, inflammation and apoptosis in the heart of streptozotocin-nicotinamide-induced adult male diabetic rats. Biomed. Pharmacother. 2017, 86, 570-582. [CrossRef]

158. Zhang, Y.; Dong, H.; Wang, M.; Zhang, J. Quercetin isolated from toona sinensis leaves attenuates hyperglycemia and protects hepatocytes in high-carbohydrate/high-fat diet and alloxan induced experimental diabetic mice. J. Diabetes Res. 2016, 2016, 1-10. [CrossRef]

159. Jeong, S.-M.; Kang, M.-J.; Choi, H.-N.; Kim, J.-H.; Kim, J.-I. Quercetin ameliorates hyperglycemia and dyslipidemia and improves antioxidant status in type 2 diabetic $\mathrm{db} / \mathrm{db}$ mice. Nutr. Res. Pr. 2012, 6, 201-207. [CrossRef]

160. Zhu, X.; Xiong, T.; Liu, P.; Guo, X.; Xiao, L.; Zhou, F.; Tang, Y.; Yao, P.; Zhu, X.; Xiong, T.; et al. Quercetin ameliorates HFD-induced NAFLD by promoting hepatic VLDL assembly and lipophagy via the IRE1a/XBP1s pathway. Food Chem. Toxicol. 2018, 114, 52-60. [CrossRef]

161. Qin, G.; Ma, J.; Huang, Q.; Yin, H.; Han, J.; Li, M.; Deng, Y.; Wang, B.; Hassan, W.; Shang, J. Isoquercetin improves hepatic lipid accumulation by activating AMPK pathway and suppressing TGF- $\beta$ signaling on an HFD-induced nonalcoholic fatty liver disease rat model. Int. J. Mol. Sci. 2018, 19, 4126. [CrossRef]

162. Zhou, J.; Yoshitomi, H.; Liu, T.; Zhou, B.; Sun, W.; Qin, L.; Guo, X.; Huang, L.; Wu, L.; Gao, M. Isoquercitrin activates the AMP-activated protein kinase (AMPK) signal pathway in rat H4IIE cells. BMC Complement. Altern. Med. 2014, 14, 42. [CrossRef]

163. Haddad, P.S.; Eid, H.M.; Nachar, A.; Thong, F.; Sweeney, G.; Haddad, P.S.; Eid, H.M.; Nachar, A.; Thong, F.; Sweeney, G. The molecular basis of the antidiabetic action of quercetin in cultured skeletal muscle cells and hepatocytes. Pharmacogn. Mag. 2015, 11, 74-81. [CrossRef]

164. Liu, K.; Mei, F.; Wang, Y.; Xiao, N.; Yang, L.; Wang, Y.; Li, J.; Huang, F.; Kou, J.; Liu, B.; et al. Quercetin oppositely regulates insulin-mediated glucose disposal in skeletal muscle under normal and inflammatory conditions: The dual roles of AMPK activation. Mol. Nutr. Food Res. 2015, 60, 551-565. [CrossRef] [PubMed]

165. Peng, J.; Li, Q.; Li, K.; Zhu, L.; Lin, X.; Lin, X.; Shen, Q.; Li, G.; Xie, X. Quercetin improves glucose and lipid metabolism of diabetic rats: Involvement of Akt signaling and SIRT1. J. Diabetes Res. 2017, 2017, 1-10. [CrossRef]

166. Guo, X.-D.; Zhang, D.-Y.; Gao, X.-J.; Parry, J.; Liu, K.; Liu, B.-L.; Wang, M. Quercetin and quercetin-3-O-glucuronide are equally effective in ameliorating endothelial insulin resistance through inhibition of reactive oxygen species-associated inflammation. Mol. Nutr. Food Res. 2013, 57, 1037-1045. [CrossRef]

167. Li, X.; Wang, R.; Zhou, N.; Wang, X.; Liu, Q.; Bai, Y.; Bai, Y.; Liu, Z.; Yang, H.; Zou, J.; et al. Quercetin improves insulin resistance and hepatic lipid accumulation in vitro in a NAFLD cell model. Biomed. Rep. 2012, 1, 71-76. [CrossRef] [PubMed]

168. Forney, L.A.; Lenard, N.R.; Stewart, L.K.; Henagan, T.M. Dietary quercetin attenuates adipose tissue expansion and inflammation and alters adipocyte morphology in a tissue-specific manner. Int. J. Mol. Sci. 2018, 19, 895. [CrossRef] [PubMed]

169. Seo, M.-J.; Lee, Y.-J.; Hwang, J.-H.; Kim, K.-J.; Lee, B.-Y. The inhibitory effects of quercetin on obesity and obesity-induced inflammation by regulation of MAPK signaling. J. Nutr. Biochem. 2015, 26, 1308-1316. [CrossRef]

170. Kobori, M.; Takahashi, Y.; Sakurai, M.; Akimoto, Y.; Tsushida, T.; Oike, H.; Ippoushi, K.; Kobori, M.; Takahashi, Y.; Sakurai, M.; et al. Quercetin suppresses immune cell accumulation and improves mitochondrial gene expression in adipose tissue of diet-induced obese mice. Mol. Nutr. Food Res. 2015, 60, 300-312. [CrossRef]

171. Porras, D.; Nistal, E.; Martínez-Flórez, S.; Pisonero-Vaquero, S.; Olcoz, J.L.; Jover, R.; González-Gallego, J.; García-Mediavilla, M.V.; Sánchez-Campos, S. Protective effect of quercetin on high-fat diet-induced non-alcoholic fatty liver disease in mice is mediated by modulating intestinal microbiota imbalance and related gut-liver axis activation. Free. Radic. Biol. Med. 2017, 102, 188-202. [CrossRef]

172. Nie, J.; Zhang, L.; Zhao, G.; Du, X. Quercetin reduces atherosclerotic lesions by altering the gut microbiota and reducing atherogenic lipid metabolites. J. Appl. Microbiol. 2019, 127, 1824-1834. [CrossRef] 
173. Wu, D.-N.; Guan, L.; Jiang, Y.-X.; Ma, S.-H.; Sun, Y.-N.; Lei, H.-T.; Yang, W.-F.; Wang, Q.-F. Microbiome and metabonomics study of quercetin for the treatment of atherosclerosis. Cardiovasc. Diagn. Ther. 2019, 9, 545-560. [CrossRef]

174. Zhang, F.; Feng, J.; Zhang, J.; Kang, X.; Qian, D. Quercetin modulates AMPK/SIRT1/NF- $\kappa B$ signaling to inhibit inflammatory/oxidative stress responses in diabetic high fat diet-induced atherosclerosis in the rat carotid artery. Exp. Ther. Med. 2020, 20, 1. [CrossRef]

175. Ghorbani, A. Mechanisms of antidiabetic effects of flavonoid rutin. Biomed. Pharmacother. 2017, 96, 305-312. [CrossRef]

176. Chalet, C.; Rubbens, J.; Tack, J.; Duchateau, G.S.; Augustijns, P. Intestinal disposition of quercetin and its phase-II metabolites after oral administration in healthy volunteers. J. Pharm. Pharmacol. 2018, 70, 1002-1008. [CrossRef] [PubMed]

177. Adeva-Andany, M.M.; Calvo-Castro, I.; Fernández-Fernández, C.; Donapetry-García, C.; Pedre-Piñeiro, A.M. Significance of 1-carnitine for human health. IUBMB Life 2017, 69, 578-594. [CrossRef] [PubMed]

178. Janeiro, M.H.; Ramírez, M.J.; Milagro, F.I.; Martínez, J.A.; Solas, M. Implication of Trimethylamine N-Oxide (TMAO) in disease: Potential biomarker or new therapeutic target. Nutrients 2018, 10, 1398. [CrossRef] [PubMed]

179. Seldin, M.M.; Meng, Y.; Qi, H.; Zhu, W.; Wang, Z.; Hazen, S.L.; Lusis, A.J.; Shih, D.M. Trimethylamine N-Oxide promotes vascular inflammation through signaling of mitogen-activated protein kinase and nuclear factor-kB. J. Am. Hear. Assoc. 2016, 5. [CrossRef] [PubMed]

180. Ma, G.; Pan, B.; Chen, Y.; Guo, C.; Zhao, M.; Zheng, L.; Chen, B. Trimethylamine N-oxide in atherogenesis: Impairing endothelial self-repair capacity and enhancing monocyte adhesion. Biosci. Rep. 2017, 37. [CrossRef]

181. Chen, M.; Zhu, X.; Ran, L.; Lang, H.; Yi, L.; Mi, M. Trimethylamine-N-Oxide induces vascular inflammation by activating the NLRP3 inflammasome through the SIRT3-SOD2-mtROS signaling pathway. J. Am. Hear. Assoc. 2017, 6, e006347. [CrossRef]

182. Canyelles, M.; Tondo, M.; Cedó, L.; Farràs, M.; Escolà-Gil, J.C.; Blanco-Vaca, F. Trimethylamine N-Oxide: A link among diet, gut microbiota, gene regulation of liver and intestine cholesterol homeostasis and HDL function. Int. J. Mol. Sci. 2018, 19, 3228. [CrossRef] [PubMed]

183. Warrier, M.; Shih, D.M.; Burrows, A.C.; Ferguson, D.; Gromovsky, A.D.; Brown, A.L.; Marshall, S.; McDaniel, A.; Schugar, R.C.; Wang, Z; i et al. The TMAO-generating enzyme flavin monooxygenase 3 is a central regulator of cholesterol balance. Cell Rep. 2015, 10, 326-338. [CrossRef]

184. Koeth, R.A.; Lam-Galvez, B.R.; Kirsop, J.; Wang, Z.; Levison, B.S.; Gu, X.; Copeland, M.F.; Bartlett, D.; Cody, D.B.; Dai, H.J.; et al. 1-Carnitine in omnivorous diets induces an atherogenic gut microbial pathway in humans. J. Clin. Investig. 2018, 129, 373-387. [CrossRef]

185. Koeth, R.A.; Wang, Z.; Levison, B.; Buffa, J.A.; Org, E.; Sheehy, B.T.; Britt, E.B.; Fu, X.; Wu, Y.; Li, L.; et al. Intestinal microbiota metabolism of L-carnitine, a nutrient in red meat, promotes atherosclerosis. Nat. Med. 2013, 19, 576-585. [CrossRef]

186. Collins, H.L.; Drazul-Schrader, D.; Sulpizio, A.C.; Koster, P.D.; Williamson, Y.; Adelman, S.J.; Owen, K.; Sanli, T.; Bellamine, A. L-Carnitine intake and high trimethylamine N-oxide plasma levels correlate with low aortic lesions in ApoE(-/-) transgenic mice expressing CETP. Atherosclerosis 2016, 244, 29-37. [CrossRef]

187. Bordoni, L.; Sawicka, A.; Szarmach, A.; Winklewski, P.J.; Olek, R.A.; Gabbianelli, R. A pilot study on the effects of 1-Carnitine and Trimethylamine-N-Oxide on platelet mitochondrial DNA methylation and CVD biomarkers in aged women. Int. J. Mol. Sci. 2020, 21, 1047. [CrossRef] [PubMed]

188. Vallance, H.; Koochin, A.; Branov, J.; Rosen-Heath, A.; Bosdet, T.; Wang, Z.; Hazen, S.; Horvath, G. Marked elevation in plasma trimethylamine-N-oxide (TMAO) in patients with mitochondrial disorders treated with oral l-carnitine. Mol. Genet. Metab. Rep. 2018, 15, 130-133. [CrossRef]

189. Wang, Z.-Y.; Liu, Y.-Y.; Liu, G.-H.; Lu, H.-B.; Mao, C.-Y. 1-Carnitine and heart disease. Life Sci. 2018, 194, 88-97. [CrossRef] [PubMed]

190. Strilakou, A.A.; Lazaris, A.C.; Perelas, A.I.; Mourouzis, I.; Douzis, I.C.; Karkalousos, P.L.; Stylianaki, A.T.; Pantos, C.I.; Liapi, C.A. Heart dysfunction induced by choline-deficiency in adult rats: The protective role of L-carnitine. Eur. J. Pharmacol. 2013, 709, 20-27. [CrossRef] [PubMed]

191. O'Brien, D.; Chunduri, P.; Iyer, A.; Brown, L. L-carnitine attenuates cardiac remodelling rather than vascular remodelling in deoxycorticosterone acetate-salt hypertensive rats. Basic Clin. Pharmacol. Toxicol. 2009, 106, 296-301. [CrossRef]

192. Li, M.; Xue, L.; Sun, H.; Xu, S. Myocardial protective effects of L-Carnitine on ischemia-reperfusion injury in patients with rheumatic valvular heart disease undergoing cardiac surgery. J. Cardiothorac. Vasc. Anesthesia 2016, 30, 1485-1493. [CrossRef]

193. Xue, M.; Chen, X.; Guo, Z.; Liu, X.; Bi, Y.; Yin, J.; Hu, H.; Zhu, P.; Zhuang, J.; Cates, C.; et al. L-Carnitine attenuates cardiac dysfunction by ischemic insults through Akt signaling pathway. Toxicol. Sci. 2017, 160, 341-350. [CrossRef]

194. Vacante, F.; Senesi, P.; Montesano, A.; Frigerio, A.; Luzi, L.; Terruzzi, I. L-Carnitine: An antioxidant remedy for the survival of cardiomyocytes under hyperglycemic condition. J. Diabetes Res. 2018, 2018, 1-12. [CrossRef]

195. Wang, X.; Liu, Y.; Zhang, C.; Song, Q. Protective effect of L-carnitine on myocardial injury in rats with heatstroke. Acta Cir. Bras. 2020, 35, e351206. [CrossRef] [PubMed]

196. Zhao, T.; Chen, S.; Wang, B.; Cai, D. L-Carnitine reduces myocardial oxidative stress and alleviates myocardial ischemiareperfusion injury by activating nuclear transcription-related factor 2 (Nrf2)/Heme Oxygenase-1 (HO-1) signaling pathway. Med. Sci. Monit. 2020, 26, e923251. [CrossRef] [PubMed] 
197. Fathizadeh, H.; Milajerdi, A.; Reiner, Ž.; Amirani, E.; Asemi, Z.; Mansournia, M.A.; Hallajzadeh, J. The effects of L-carnitine supplementation on indicators of inflammation and oxidative stress: A systematic review and meta-analysis of randomized controlled trials. J. Diabetes Metab. Disord. 2020, 19, 1879-1894. [CrossRef]

198. Li, M.; Xu, S.; Geng, Y.; Sun, L.; Wang, R.; Yan, Y.; Wang, H.; Li, Y.; Yi, Q.; Zhang, Y.; et al. The protective effects of L-carnitine on myocardial ischaemia-reperfusion injury in patients with rheumatic valvular heart disease undergoing $\mathrm{CPB}$ surgery are associated with the suppression of NF-kB pathway and the activation of Nrf2 pathway. Clin. Exp. Pharmacol. Physiol. 2019, 46, 1001-1012. [CrossRef]

199. Samir, S.M.; Abbas, A.M.; Safwat, S.M.; Elserougy, H.G. Effect of L-carnitine on diabetes-induced changes of skeletal muscles in rats. J. Basic Clin. Physiol. Pharmacol. 2017, 29, 47-59. [CrossRef]

200. Mollica, G.; Senesi, P.; Codella, R.; Vacante, F.; Montesano, A.; Luzi, L.; Terruzzi, I. L-carnitine supplementation attenuates NAFLD progression and cardiac dysfunction in a mouse model fed with methionine and choline-deficient diet. Dig. Liver Dis. 2020, 52, 314-323. [CrossRef]

201. Abolfathi, M.; Mohd-Yusof, B.-N.; Hanipah, Z.N.; Redzwan, S.M.; Yusof, L.M.; Khosroshahi, M.Z. The effects of carnitine supplementation on clinical characteristics of patients with non-alcoholic fatty liver disease: A systematic review and metaanalysis of randomized controlled trials. Complement. Ther. Med. 2020, 48, 102273. [CrossRef]

202. Montesano, A.; Senesi, P.; Vacante, F.; Mollica, G.; Benedini, S.; Mariotti, M.; Luzi, L.; Terruzzi, I. L-Carnitine counteracts in vitro fructose-induced hepatic steatosis through targeting oxidative stress markers. J. Endocrinol. Investig. 2019, 43, 493-503. [CrossRef]

203. Sayed-Ahmed, M.M.; Alrufaiq, B.I.; AlRikabi, A.; Abdullah, M.L.; Hafez, M.M.; Al-Shabanah, O.A. Carnitine supplementation attenuates sunitinib-induced inhibition of AMP-activated protein kinase downstream signals in cardiac tissues. Cardiovasc. Toxicol. 2019, 19, 344-356. [CrossRef]

204. Zhao, Y.; Yang, N.; Gao, J.; Li, H.; Cai, W.; Zhang, X.; Ma, Y.; Niu, X.; Yang, G.; Zhou, X.; et al. The effect of different 1-Carnitine administration routes on the development of atherosclerosis in ApoE knockout mice. Mol. Nutr. Food Res. 2018, 62. [CrossRef]

205. Shih, D.M.; Zhu, W.; Schugar, R.C.; Meng, Y.; Jia, X.; Miikeda, A.; Wang, Z.; Zieger, M.; Lee, R.; Graham, M.; et al. Genetic deficiency of Flavin-Containing Monooxygenase 3 ( Fmo3) protects against thrombosis but has only a minor effect on plasma lipid levels-brief report. Arter. Thromb. Vasc. Biol. 2019, 39, 1045-1054. [CrossRef] [PubMed]

206. Bennett, B.J.; Vallim, T.Q.D.A.; Wang, Z.; Shih, D.M.; Meng, Y.; Gregory, J.; Allayee, H.; Lee, R.; Graham, M.; Crooke, R.; et al. Trimethylamine-N-oxide, a metabolite associated with atherosclerosis, exhibits complex genetic and dietary regulation. Cell Metab. 2013, 17, 49-60. [CrossRef] [PubMed]

207. Annunziata, G.; Maisto, M.; Schisano, C.; Ciampaglia, R.; Narciso, V.; Tenore, G.C.; Novellino, E. Effects of Grape Pomace Polyphenolic Extract (Taurisolo ${ }^{\circledR}$ ) in Reducing TMAO Serum Levels in Humans: Preliminary Results from a Randomized, Placebo-Controlled, Cross-Over Study. Nutrients. 2019, 11, 139. [CrossRef] [PubMed]

208. Gautam, A.; Paudel, Y.N.; Abidin, S.; Bhandari, U. Guggulsterone, a farnesoid X receptor antagonist lowers plasma trimethylamine-N-oxide levels: An evidence from in vitro and in vivo studies. Hum. Exp. Toxicol. 2018, 38, 356-370. [CrossRef] [PubMed]

209. Baksi, A.; Kraydashenko, O.; Zalevkaya, A.; Stets, R.; Elliott, P.; Haddad, J.; Hoffmann, E.; Vlasuk, G.P.; Jacobson, E.W. A phase II, randomized, placebo-controlled, double-blind, multi-dose study of SRT2104, a SIRT1 activator, in subjects with type 2 diabetes. Br. J. Clin. Pharmacol. 2014, 78, 69-77. [CrossRef]

210. Noh, R.M.; Venkatasubramanian, S.; Daga, S.; Langrish, J.; Mills, N.L.; Lang, N.N.; Hoffmann, E.; Waterhouse, B.; Newby, D.E.; Frier, B.M. Cardiometabolic effects of a novel SIRT1 activator, SRT2104, in people with type 2 diabetes mellitus. Open Hear. 2017, 4. [CrossRef]

211. Venkatasubramanian, S.; Noh, R.M.; Daga, S.; Langrish, J.P.; Mills, N.; Waterhouse, B.R.; Hoffmann, E.; Jacobson, E.W.; Lang, N.; Frier, B.M.; et al. Effects of the small molecule SIRT1 activator, SRT2104 on arterial stiffness in otherwise healthy cigarette smokers and subjects with type 2 diabetes mellitus. Open Hear. 2016, 3, e000402. [CrossRef]

212. Mautone, N.; Zwergel, C.; Mai, A.; Rotili, D. Sirtuin modulators: Where are we now? A review of patents from 2015 to 2019. Expert Opin. Ther. Patents 2020, 30, 389-407. [CrossRef]

213. Chen, J.; Cao, J.; Fang, L.; Liu, B.; Zhou, Q.; Sun, Y.; Wang, Y.; Li, Y.; Meng, S.; Chen, J.; et al. Berberine derivatives reduce atherosclerotic plaque size and vulnerability in apoE(-/-) mice. J. Transl. Med. 2014, 12, 326. [CrossRef]

214. Wang, J.-T.; Peng, J.-G.; Zhang, J.-Q.; Wang, Z.-X.; Zhang, Y.; Zhou, X.-R.; Miao, J.; Tang, L. Novel berberine-based derivatives with potent hypoglycemic activity. Bioorganic Med. Chem. Lett. 2019, 29, 126709. [CrossRef]

215. Li, A.; Zhang, S.; Li, J.; Liu, K.; Huang, F.; Liu, B.; Li, A.; Zhang, S.; Li, J.; Liu, K.; et al. Metformin and resveratrol inhibit Drp1-mediated mitochondrial fission and prevent ER stress-associated NLRP3 inflammasome activation in the adipose tissue of diabetic mice. Mol. Cell. Endocrinol. 2016, 434, 36-47. [CrossRef]

216. Frendo-Cumbo, S.; MacPherson, R.; Wright, D.C. Beneficial effects of combined resveratrol and metformin therapy in treating diet-induced insulin resistance. Physiol. Rep. 2016, 4, e12877. [CrossRef] [PubMed]

217. Zhu, X.; Yang, J.; Zhu, W.; Yin, X.; Yang, B.; Wei, Y.; Guo, X. Combination of berberine with resveratrol improves the lipid-lowering efficacy. Int. J. Mol. Sci. 2018, 19, 3903. [CrossRef] [PubMed]

218. Zhao, L.; Zhang, Q.; Ma, W.; Tian, F.; Shen, H.; Zhou, M. A combination of quercetin and resveratrol reduces obesity in high-fat diet-fed rats by modulation of gut microbiota. Food Funct. 2017, 8, 4644-4656. [CrossRef] [PubMed] 
219. Mattson, M.P.; Longo, V.D.; Harvie, M. Impact of intermittent fasting on health and disease processes. Ageing Res. Rev. 2017, 39, 46-58. [CrossRef]

220. Longo, V.D.; Panda, S. Fasting, circadian rhythms, and time-restricted feeding in healthy lifespan. Cell Metab. 2016, 23, 1048-1059. [CrossRef]

221. McGee, S.L.; Hargreaves, M. Exercise adaptations: Molecular mechanisms and potential targets for therapeutic benefit. Nat. Rev. Endocrinol. 2020, 16, 495-505. [CrossRef]

222. Montesano, A.; Senesi, P.; Luzi, L.; Benedini, S.; Terruzzi, I. Potential therapeutic role of L-carnitine in skeletal muscle oxidative stress and atrophy conditions. Oxidative Med. Cell. Longev. 2015, 2015, 1-13. [CrossRef] [PubMed] 